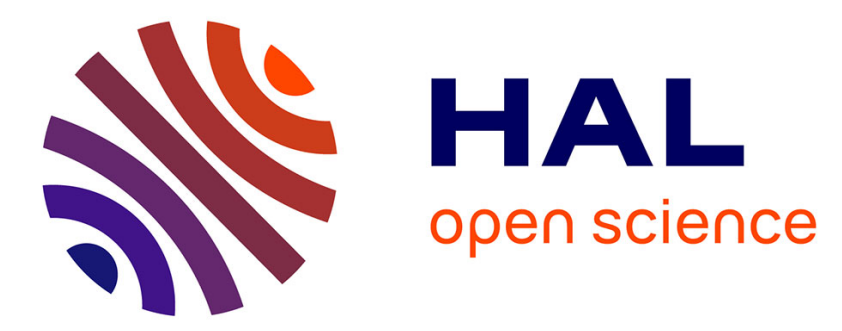

\title{
A biogenic tunable sorbent produced from upcycling of aquatic biota-based materials functionalized with methylene blue dye for the removal of chromium(VI) ions
}

\author{
Khalid Elwakeel, Ahmed Elgarahy, Eric Guibal
}

\section{To cite this version:}

Khalid Elwakeel, Ahmed Elgarahy, Eric Guibal. A biogenic tunable sorbent produced from upcycling of aquatic biota-based materials functionalized with methylene blue dye for the removal of chromium(VI) ions. Journal of Environmental Chemical Engineering, 2021, 9 (2), pp.104767. 10.1016/j.jece.2020.104767 . hal-03035260

\section{HAL Id: hal-03035260 \\ https://hal.mines-ales.fr/hal-03035260}

Submitted on 2 Dec 2020

HAL is a multi-disciplinary open access archive for the deposit and dissemination of scientific research documents, whether they are published or not. The documents may come from teaching and research institutions in France or abroad, or from public or private research centers.
L'archive ouverte pluridisciplinaire HAL, est destinée au dépôt et à la diffusion de documents scientifiques de niveau recherche, publiés ou non, émanant des établissements d'enseignement et de recherche français ou étrangers, des laboratoires publics ou privés. 


\title{
A biogenic tunable sorbent produced from upcycling of aquatic biota-based materials functionalized with methylene blue dye for the removal of chromium(VI) ions
}

\author{
Khalid Z. Elwakeel $^{\mathrm{a}, \mathrm{b}}$, Ahmed M. Elgarahy ${ }^{\mathrm{a}}$, Eric Guibal ${ }^{\mathrm{c}, *}$ \\ ${ }^{a}$ Environmental Science Department, Faculty of Science, Port-Said University, Port-Said, Egypt \\ ${ }^{\mathrm{b}}$ Department of Chemistry, College of Science, University of Jeddah, Jeddah, Saudi Arabia \\ ${ }^{\mathrm{c}}$ Polymers Composites and Hybrids (PCH), IMT Mines Ales, Alès, France
}

A B S T R A C T

The valorization of algal biomass and bi-valve shells allows synthesizing, in the presence of urea, a sorbent highly efficient for methylene blue (MB) sorption (sorption capacity: $1.5 \mathrm{mmol} \mathrm{MB} \mathrm{g}^{-1}$ at $\mathrm{pH}$ 5.8). The dye- functionalized sorbent shows enhanced sorption properties for Cr(VI) recovery at $\mathrm{pH} 3$. The

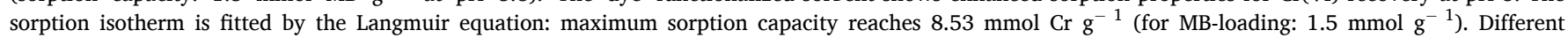
mechanisms may be involved such as the electrostatic attraction of anionic species, che-lation on reactive groups, reduction of Cr(VI) into Cr(III). Under selected experimental conditions, the sorption is achieved within less than $60 \mathrm{~m}$. The kinetic profiles are controlled by the pseudo-second order rate equation. Alkaline $\mathrm{NaCl}$ solutions effciently desorb chromate while maintaining a good stability of the dye (negligible release). Therefore, the sorption and desorption performances are maintained remarkably stable for at least 5 sorption/desorption cycles. The sorbent is successfully applied for chromate recovery from Cr(VI)-spiked solu-tions (tap water and wastewater from petrochemical unit) with limited loss in sorption performances. The sor-bent is characterized by BET, TGA, FTIR, SEM, EDX and zetametry to help in the understanding of binding mechanisms and sorption performances.

Keywords:

Dye-functionalization

Alginate beads

Upcycling

Chromate sorption

Sorbent recycling

\section{Introduction}

The growing industrial activity, concomitantly with agriculture and urban uses, puts pressure on water demand. The contamination of water bodies (surface, groundwater and industrial wastewater) is thus a critical point that attracts the attention of communities [1,2] and motivates increasingly strict international regulations and government policies. Dyes and metal ions are emblematic examples of contaminants that affect water bodies and limit their use for agriculture and drinking purposes. These hazardous substances are strictly controlled to prevent their dumping into the aquatic environment and limit their carcinogenic and mutagenic potential impacts on biotope, animals and human beings $[3,4]$. For example, methylene blue (MB) is one of the synthetic cationic dyes the most extensively employed in various industries such as dyeing stuff, papermaking, pesticides, cosmetics and others, due to its great water solubility and color stability [5,6]. Being non-biodegradable, having carcinogenic and mutagenic effects, it may cause serious damages to human health. Accidental contact with MB can induce shock, cyanosis, heart palpitation enhancement, vomiting, jaundice, quadriplegia and tissue necrosis. Strong exposure to MB (corresponding to an intake $>7.0 \mathrm{mg} \mathrm{kg}^{-1}$ ) was reported to increase blood pressure and to cause abdominal pain, nausea and mental disorder [5,7].

Chromium is also an emblematic example of hazardous metals, widely used in industries such as electroplating, leather tanning, textiles, fertilizers, stainless steel, welding and wood preservation. Chromate (i. e., $\mathrm{Cr}(\mathrm{VI})$ ) is the most toxic form of chromium for the aquatic environment [8]. Indeed, low concentrations are sufficient for causing DNA damages, digestive problems, skin ulceration, kidney, respiratory diseases and cancer [9]. The International Agency for Research on Cancer (IARC) classified chromate as a Group I substance (i.e., human carcinogen). The USEPA (United States Environmental Protection Agency), the EU (European Union) and the WHO (World Health Organization) reported strict regulations on chromate to $0.05 \mathrm{mg} \mathrm{L}^{-1}$ for drinking water and $0.1 \mathrm{mg} \mathrm{L}^{-1}$ for discharge levels in industrial wastewater $[10,11]$. A

\footnotetext{
* Corresponding author at: Polymers Composites and Hybrids (PCH), IMT - Mines Ales, Alès, France.

E-mail addresses: khalid_elwakeel@sci.psu.edu.eg (K.Z. Elwakeel), Eric.Guibal@mines-ales.fr (E. Guibal).
} 


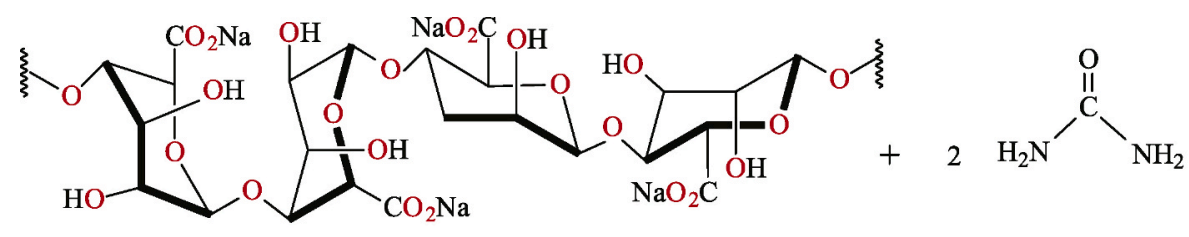

Sodium alginate
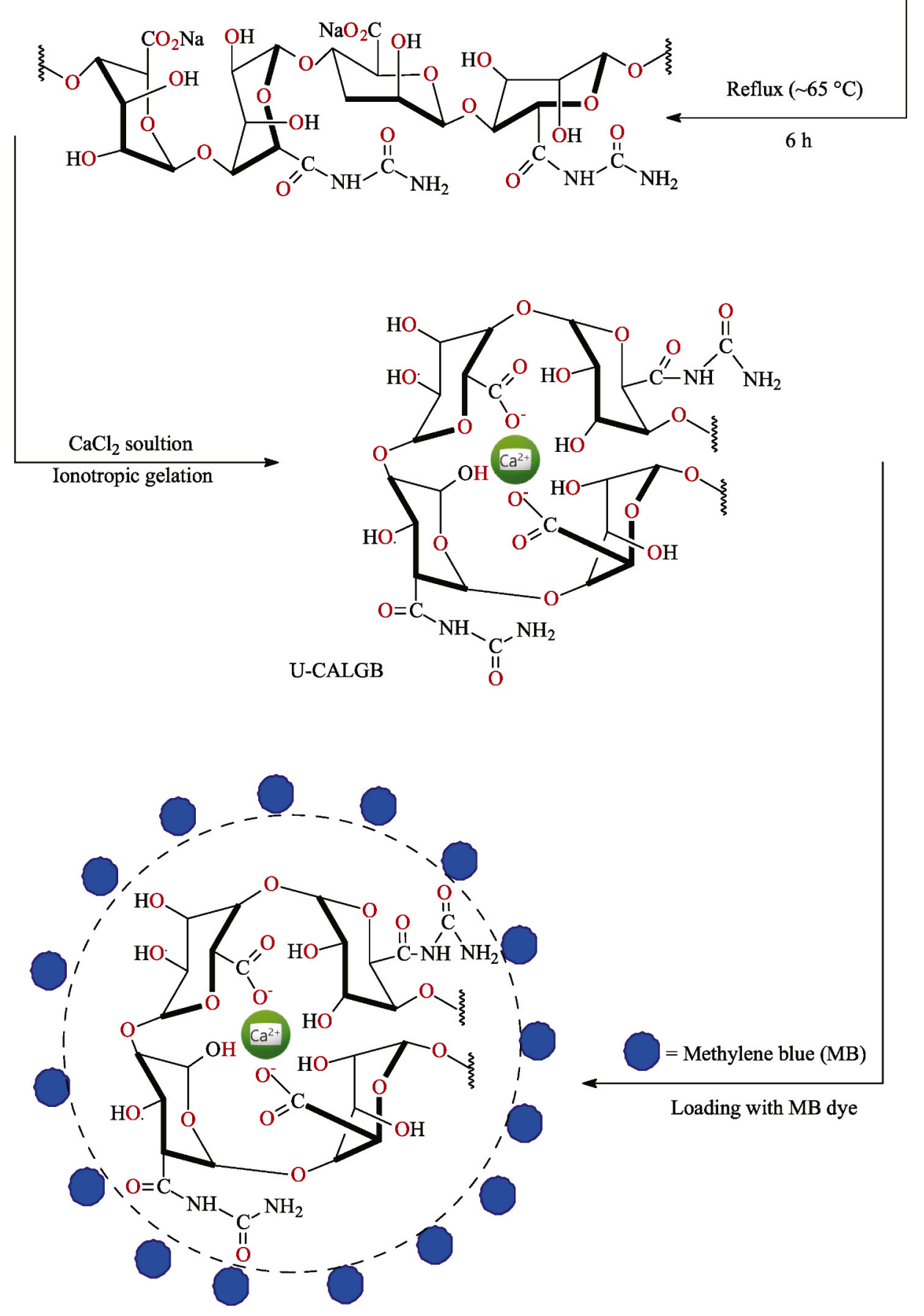

Scheme 1. Synthesis route for the preparation of U-CALGB-MB 1.5 .

wide diversity of treatment processes have been developed for the last decades for removing chromium from aqueous solutions including chemical precipitation [12], coagulation [13], solvent extraction [14], ion exchange [15] and membrane separation [16]. These techniques are frequently facing limitations in terms of cost analysis removal efficiency, or inappropriateness to industrial requirements (relative to flow rate and/or metal concentration range). Adsorption can be used industrially to recover the metal ions for further reuse and is cost-effective and 
time-effective as well [17]. Recently, alternative sorbents have been tested for $\mathrm{Cr}(\mathrm{VI})$ recovery including activated carbon [18,19], biochar [20], hydroxyapatite [21], biomass [22] and nanocomposites [23]. Biosorbents have also retained great attention for designing sorbents for metal recovery, including chromate anions [24-27]. Based on materials of biological origin (or derived from), these materials (such as algal biomass [28] and chitosan [29]) have similar reactive groups than those found on ion exchange or chelating resins .

International policies are promoting the "waste to wealth" strategy through valorizing wastes for decreasing their impact on the environment, diminishing the consumption of primary resources with cost benefit. This is precisely the directives that have been followed for designing the new sorbent tested in this study. The sustainable upcycling of abundant wastes present on Egyptian costs that are currently poorly or not valorized in contributing to a green circular economy. Two untapped waste biomass (i.e., brown algae and bivalve shells) have been used for designing urea calcium alginate beads (U-CALGB). These resources are generally thrown. Herein, algal biomass (Padina boergesenii) is used for extracting alginate, while bivalve shells (Anadara uropigimelana) are treated for producing calcium chloride. First, extracted alginate is ionotropically gelled into calcium chloride solution to produce calcium alginate beads that are functionalized with urea (UCALGB). This sorbent is used for binding methylene blue (MB) and synthesize a new sorbent (U-CALGB-MB $\mathrm{x}_{\mathrm{x}} \mathrm{x}$ variable, mmol $\mathrm{MB} \mathrm{g}^{-1}$, associated with MB loading). Indeed, the functionalization of sorbents with complexing dyes has been reported to enhance the sorption properties of these supports $[30,31]$. The materials are characterized using BET, TGA, FTIR and titration. The sorption isotherm of MB on UCALGB is first obtained at $\mathrm{pH} 5.8$ before investigating the impact of MB loading on $\mathrm{Cr}(\mathrm{VI})$ sorption. After this preliminary study that optimizes $\mathrm{MB}$ loading to produce U-CALGB-MB ${ }_{1.5}$, the sorbent is investigated for $\mathrm{Cr}$ (VI) sorption for evaluating the effect of $\mathrm{pH}$, sorbent dosage, uptake kinetics, sorption isotherms, temperature and presence of $\mathrm{NaCl}$. The readily reduction of chromate into $\mathrm{Cr}(\mathrm{III})$ has been widely documented $[32,33]$ and used for improving metal removal; this phenomenon has been taken into account in the discussion of experimental data. The desorption of chromate and the recycling of the sorbent are also carried out before testing the efficiency of chromate sorption on real solutions (spiked tap water and petrochemical unit effluent).

\section{Materials and methods}

\subsection{Materials}

Alginate-based material used for the synthesis of sorbent was extracted from Padina boergesenii brown algae. This algal biomass was collected on Red Sea coast (Hurghada, Egypt) in January 2020. Calcium chloride used for the ionotropic gelation of algal-based beads was obtained from beach bivalve shells (Anadara uropigimelana) collected on Port-Said coast (Egyptian Mediterranean seaside) in February 2020. These samples were carefully cleaned-up after collection; a first tap water rinsing was processed before demineralized water thrice washing $\left(0.06 \mu \mathrm{cm}^{-1}\right)$ to eliminate any impurities deposited at the surface of algal and bivalve substrates. The washed-up materials were air-dried for 3 days before being dried in an oven (Weiss Gallenkamp, Model OV-160, Loughborough, UK) at $38{ }^{\circ} \mathrm{C}$ for $6 \mathrm{~h}$ (constant weight).

Acetone, ethanol, urea, formaldehyde, sodium carbonate, sodium chloride sodium hypochlorite and methylene blue ( $\mathrm{MB}, \mathrm{C}_{16} \mathrm{H}_{18} \mathrm{~N}_{3} \mathrm{SCl}$ ) were purchased, as standard analytical grade reagents from SigmaAldrich (Darmstadt, Germany). Potassium dichromate, used as $\mathrm{Cr}(\mathrm{VI})$ source, was supplied by Fluka AG (Buchs, Switzerland). 1,5-Diphenylcarbazide was provided by Hach Company (Loveland, CO, USA).

\subsection{Synthesis of biogenic tunable sorbent}

\subsubsection{Alginate production}

Dried algal biomass was first milled using pestle and mortar. The material was then subjected to three successive extraction steps [31]:

(a) phenolic compounds were first extracted from algal biomass (15 g) by treatment with formaldehyde solution $(500 \mathrm{~mL}, 4 \%$, w/w) for $40 \mathrm{~min}$, followed by soaking in $0.1 \mathrm{M} \mathrm{HCl}$ solution $(200 \mathrm{~mL})$ for $3 \mathrm{~h}$.

(b) alginate extraction was operated by contact of the treated biomass with a $\mathrm{Na}_{2} \mathrm{CO}_{3}$ solution $(2 \%, \mathrm{w} / \mathrm{w})$ at $60{ }^{\circ} \mathrm{C}$ for $6 \mathrm{~h}$ : alginic acid is converted into sodium alginate.

(c) precipitation of sodium alginate was carried out in ethanol solution after a filtration step that allowed removing the solid impurities. Sodium alginate (SA) production yield reached $38.2 \pm$ $1.2 \%$.

\subsubsection{Bio-originated calcium chloride}

The synthesis of bio-originated calcium chloride was operated following:

(a) washing of grinded dried bivalve shells using acetone under agitation for $40 \mathrm{~min}$; the steps allow decolorizing the shells).

(b) after air-drying for $5 \mathrm{~h}$, the shells were treated with sodium hypochlorite for $6 \mathrm{~h}$; this step corresponds to the bleaching of the shells.

(c) treated shells were rinsed with tap water and finally with demineralized water (thrice) and dried in an oven for $3{ }^{\circ} \mathrm{C}$ at $100{ }^{\circ} \mathrm{C}$.

(d) $\mathrm{CaCO}_{3}$ fine powder was obtained by chopping the shells, screening the fraction below $1 \mathrm{~mm}$ and final drying for $2 \mathrm{~h}$ at 100 ${ }^{\circ} \mathrm{C}$. The production yield reached $94.7 \pm 1.0 \%$.

(e) $25 \mathrm{~g}$ of $\mathrm{CaCO}_{3}$ were converted into $\mathrm{CaCl}_{2}$ solution by reaction with $1 \mathrm{M} \mathrm{HCl}$ solution $(250 \mathrm{~mL}$ ) for $2 \mathrm{~h}$ under agitation (i.e., 400 rpm).

\subsubsection{Synthesis of urea-functionalized calcium alginate xerogel beads ( $U$ -}

\section{CALGB)}

Three $\mathrm{g}$ of urea were dissolved into $100 \mathrm{~mL}$ of demineralized water and $3 \mathrm{~g}$ of SA in a two-necked round flask. The mixture was maintained for $6 \mathrm{~h}$ under reflux $\left(\sim 65^{\circ} \mathrm{C}\right)$. In a second step, the thick slurry was added dropwise through a $0.75-\mathrm{mm}$ nozzle into the ionotropic gelation bath (i.e., $\mathrm{CaCl}_{2}$ solution) under gentle agitation (i.e., $200 \mathrm{rpm}$ ) using a reciprocal shaker (Rotabit, J.P. Selecta, Barcelona, Spain). The reaction took place for $2 \mathrm{~h}$ at room temperature (i.e., $25 \pm 1{ }^{\circ} \mathrm{C}$ ). Afterward, the beads were stored for $24 \mathrm{~h}$ at $4{ }^{\circ} \mathrm{C}$ in the $\mathrm{CaCl}_{2}$ solution, for completion of ionotropic gelation (Scheme 1). After separation from the ionotropic gelation bath, the beads (U-CALGB) were abundantly rinsed with demineralized water (for removing unbound calcium), and air-dried for 3 days at room temperature. In order to evaluate the contribution of urea, reference calcium alginate beads (CALGB) were prepared, based on the same procedure. Urea was not introduced; the SA solution (from algal biomass) was directly dropped through the same thin nozzle into the calcium chloride solution (produced from bi-valve treatment). The final steps were identical to U-CALGB synthesis.

\subsection{Methylene blue sorption - synthesis of MB-decorated sorbent}

The impregnation/sorption of MB was performed in batch under agitation $(\sim 200 \mathrm{rpm})$ by contact for $180 \mathrm{~min}$ of the beads with the dye solution at $\mathrm{pH}$ 5.4. The sorbent dosage (SD) was set to $1.5 \mathrm{~g} \mathrm{~L}^{-1}$, while different stocks of decorated beads were produced increasing the concentration of the dye $\left(\mathrm{C}_{0}\right)$ from 0.312 to $3.12 \mathrm{mmol} \mathrm{MB} \mathrm{L}^{-1}$ (Scheme 1 ). After completion, the beads were recovered by centrifugation while the supernatant was analyzed using U/VIS spectrophotometer (T70+, PG Instruments Ltd, Luttenworth, UK) at the characteristics wavelength of 
MB (i.e., $665 \mathrm{~nm}$ ) for determining the residual concentration of the dye $\left(\mathrm{C}_{\mathrm{eq}}, \mathrm{mmol} \mathrm{L}^{-1}\right)$. The sorption capacity $\left(\mathrm{q}_{\mathrm{eq}}, \mathrm{mmol} \mathrm{g}^{-1}\right)$ was determined by the mass balance equation:

$q_{e q}=\frac{\left(C_{0}-C_{e q}\right)}{S D}$

The beads were air-dried for $24 \mathrm{~h}$ at room temperature; the beads were referred to their $\mathrm{MB}$ content $\left(\mathrm{x}=\mathrm{q}_{\mathrm{eq}}, \mathrm{mmol} \mathrm{MB}^{-1}\right)$ : $\mathrm{U}_{-} \mathrm{CALGB}_{\mathrm{x}}$. Fig. S1 shows the aspect of the beads before and after MB sorption.

\subsection{Material characterization}

The characteristics of the sorbent have been analyzed using a scanning electron microscope coupled with an energy dispersive X-ray analyzer (SEM-EDX, JSM-6510LV, JEOL ltd, Tokyo, Japan) for morphology and semi-quantitative analysis. FTIR spectra were recorded on a Nicolet IS10 FT-IR equipment (ThermoScientific, Waltham, MA, USA). Thermal properties were characterized using TGA equipment (TGA-50, Shimadzu Corporation, Tokyo, Japan) (ramp rate: $15^{\circ} \mathrm{C} / \mathrm{min}$, under $\mathrm{N}_{2}$ atmosphere). Surface analysis was performed using a Quantachrome NOVA 3200e BET analyzer (Quantachrome, Anton Par, Graz, Austria) for determination of BET surface, pore volume and pore diameter (samples were degassed at $160^{\circ} \mathrm{C}$ under vacuum for $4 \mathrm{~h}$, with a ramp rate of $10{ }^{\circ} \mathrm{C} / \mathrm{min}$ and liquid $\mathrm{N}_{2}$ sorption was carried out at $77 \mathrm{~K}$ ). The surface charge of the materials was measured using a Nano Zeta sizer (Nano-ZS Malvern Instruments, London, UK).

\subsection{Sorption study}

Standard conditions for the study of $\mathrm{Cr}(\mathrm{VI})$ sorption consisted of the batch agitation $(\sim 200 \mathrm{rpm})$ of the sorbent $\left(\mathrm{U}-\mathrm{CALGB}_{\mathrm{x}}\right)$ with chromate solution at $\mathrm{pH}_{0} 3$ (initial $\mathrm{pH}$ ) with a fixed concentration of chromate $\left(100 \mathrm{mg} \mathrm{L}^{-1} ; 1.923 \mathrm{mmol} \mathrm{Cr} \mathrm{L}^{-1}\right.$ ). The sorbent dosage was set to $1.5 \mathrm{~g}$ $\mathrm{L}^{-1}$; the contact time was $90 \mathrm{~min}$ and the temperature was $25 \pm 1{ }^{\circ} \mathrm{C}$. Specific experimental conditions were used for investigating the impact of sorbent dosage (SD: $0.5-5 \mathrm{~g} \mathrm{~L}^{-1}$ ), $\mathrm{pH}_{0}(1.2-11.3)$, temperature $\left(25-55{ }^{\circ} \mathrm{C}\right.$ ), concentration (for isotherms: $0.1923-19.23 \mathrm{mmol} \mathrm{Cr} \mathrm{L}^{-1}$ ), contact time (for uptake kinetics: $0-180 \mathrm{~min}$ ). The $\mathrm{pH}$ was not controlled during the sorption processing, but the final $\mathrm{pH}$ (i.e., $\mathrm{pH}_{\mathrm{eq}}$ ) was systematically monitored at the end of the experiments (using an Aqualytic AL15 pH-meter, Dortmund, Germany). The redox potential (ORP, $\mathrm{mV}$ ) was measured using a HQ11d portable $\mathrm{pH} / \mathrm{ORP}$ meter (Hach, Ames, IA, USA). The standard MB loading was $1.5 \mathrm{mmol} \mathrm{MB}$ per $\mathrm{g}$ of sorbent; however, a preliminary test was performed with variable MB loadings. The concentration of chromate in the solution (before and after sorption) was measured using the so-called 1,5-diphenylcarbazide colorimetric method: a purple-pink complex is formed in acidic conditions and analyzed at $\lambda: 540 \mathrm{~nm}$ against a calibration curve [34]. For the study of $\mathrm{pH}$ effect, samples were simultaneously analyzed by the colorimetric method and by ICP-MS (inductively coupled plasma mass spectrometry, ICP-MS Elan 9000, PerkinElmer, Boston, MA, USA) for determining total chromium concentration. Uptake kinetics were obtained by withdrawing samples at regular contact times and analyzing the residual concentration; the sorption capacity was calculated from the mass balance equation (after correcting the volume of the solution from the withdrawn volume, for each collected sample).

$\mathrm{q}(\mathrm{t})=\sum_{i=1}^{n} \frac{\left(C(t)_{i-1}-C(t)_{i}\right) \times V(t)_{i-1}}{m}$

The effect of increasing ionic strength was approached by comparing the sorption properties in the presence of increasing concentrations of $\mathrm{NaCl}$ (in the range: $0.085-0.769 \mathrm{mmol} \mathrm{L}^{-1}$ ).

For the study of thermodynamic characteristics, sorption tests were performed in a shaking incubator (LSI3016R, LabTech S.r.l., Sorisole, Italy) using the same methodology.

The recycling of the sorbent was tested for five successive cycles under identical conditions (i.e., SD: $1.5 \mathrm{~g} \mathrm{~L}^{-1}, \mathrm{C}_{0}$ : $1.92 \mathrm{mmol} \mathrm{Cr} \mathrm{L}^{-1}$; agitation: $200 \mathrm{rpm}$; $\mathrm{T}: 25 \pm 1{ }^{\circ} \mathrm{C}$, contact time: $90 \mathrm{~min}$, for the sorption step). Sorption capacity was determined by the mass balance equation after solid/liquid separation. The sorbent was rinsed with demineralized water before being desorbed using saturated alkaline $\mathrm{NaCl}$ solution (i.e., $2 \mathrm{M} \mathrm{NaCl} / 0.5 \mathrm{M} \mathrm{NaOH}$ ) under agitation for $30 \mathrm{~min}$. After rinsing and drying at $60{ }^{\circ} \mathrm{C}$ for $4 \mathrm{~h}$, the sorbent was re-used for the next sorption cycle. The desorption efficiency was calculated by comparing the amount of chromate released with the amount sorbed.

Note: specific experimental conditions are systematically reported in the caption of the figures.

\subsection{Modeling of sorption properties}

The uptake kinetics and sorption isotherm have been modeled using conventional equations: (a) pseudo-first order rate equation (PFORE), pseudo-second order rate equation (PSORE), the Crank equation (resistance to intraparticle diffusion, RIDE), and the Elovich equation, for uptake kinetics, and (b) Langmuir, Freundlich, Sips and Temkin equations for sorption isotherms. Table S1a-b reports the relevant equations (see Supplementary Information, SI). The parameters of these models have been determined by non-linear regression analysis. The comparison of the different models was based on the quality of the fits using the determination coefficients (comparison of fitted and experimental data) and AIC (Akaike Information Criterion).

\subsection{Sorption tests on real-like effluents}

In order to approach the conditions of application on real effluents similar tests were performed on $\mathrm{Cr}(\mathrm{VI})$-spiked solutions collected from (a) tap water network in port-Said (Egypt) and (b) at the outlet of a petrochemical unit. The samples were collected and immediately stored at $5{ }^{\circ} \mathrm{C}$ before adding increasing concentrations of chromate and processing sorption tests (under standard conditions, see above). The impact of complex solutions (see Table S2, for the composition of the collected samples) on the sorption efficiency/sorption capacity ( $\mathrm{q}_{\text {ind }}$, mmol $\mathrm{Cr} \mathrm{g}^{-1}$ ). The utilization of sorption sites (UOS, \%) was calculated by comparison with a synthetic pure solution $\left(\mathrm{q}_{\mathrm{ref}}, \mathrm{mmol} \mathrm{Cr}^{-1}\right)$ under identical experimental conditions (UOS $\left.=100 \times \mathrm{q}_{\text {ind }} / \mathrm{q}_{\mathrm{ref}}\right)$.

\section{Results and discussion}

\subsection{Characterization of materials}

\subsubsection{SEM, SEM-EDX and DLS}

The morphology of the beads is roughly spherical (Fig. S1a,b, see SI) in the web state. After air-drying, the beads deform as ovoid objects with a flat surface (surface in contact with the drying container) with short cracks (Fig. S1c). With the increase of the magnification, the irregular surface clearly appears; the shrinking of the beads causes the formation of folds and streaks at the surface of the beads (Fig. S1d-f). The semiquantitative EDX analysis of the surface of the beads shows the presence of high concentration of nitrogen (i.e., $34 \% \mathrm{w} / \mathrm{w} ; 34.65 \%$ atomic fraction and $24.27 \mathrm{mmol} \mathrm{N} \mathrm{g}^{-1}$, Fig. S1g): the incorporation of urea is highly efficient. Calcium is associated with the ionotropic gelation of alginate.

Differential light scattering analysis shows a relatively symmetrical distribution of particle size for U-CALGB-MB ${ }_{1.5}$ sorbent centered on 3.17 mm (Fig. S2).

\subsubsection{Textural analysis - BET surface area}

Fig. S3 shows the $\mathrm{N}_{2}$ adsorption/desorption isotherm hysteresis of $\mathrm{U}$ CALGB and U-CALGB-MB 1.5 materials. The general shape of these BET profiles is characterized by a limited hysteresis effect between adsorption and desorption branches (in the range $\mathrm{p} / \mathrm{p}_{0}$ : $0.5-1$ ). The form of the isotherms follows the conventional Type-II profile according to IUPAC 
classification [35]. The specific surface is measured at $16.12 \mathrm{~m}^{2} \mathrm{~g}^{-1}$. The drying of alginate-based beads induces a collapse of the structure [36]; the residual porosity is relatively limited. As an example, Valentin et al. [36] reported specific surface area (SSA) close to $2 \mathrm{~m}^{2} \mathrm{~g}^{-1}$ for alginate xerogel (air-drying) while when the alginate beads were dried under supercritical $\mathrm{CO}_{2}$ condition, the aerogels exhibit SSA values higher than $300 \mathrm{~m}^{2} \mathrm{~g}^{-1}$ [37]. From BET isotherm, it was possible deducing the pore size distribution of the material applying the BJH method: pore volume reaches $0.086 \mathrm{~cm}^{3} \mathrm{~g}^{-1}$ and average pore size is $4.713 \mathrm{~nm}$. The sorbent can be classified as a mesoporous sorbent. The MB-functionalized sorbent shows textural properties of the same order of magnitude. However, the binding of the dye induces a little restriction of porous properties: the specific surface decreases to $12.1 \mathrm{~m}^{2} \mathrm{~g}^{-1}$ while the porous volume and the average pore width decrease to $0.062 \mathrm{~cm}^{3} \mathrm{~g}^{-1}$ and $4.23 \mathrm{~nm}$, respectively. The immobilization of MB creates supplementary linkages, and steric hindrance, which, in turn, contribute to the weakened porous properties.

\subsubsection{Thermogravimetric analysis}

The TGA profiles for the thermal degradation of U-CALGB and UCALGB-MB ${ }_{1.5}$ are summarized in Fig. S4. The weight loss at $800{ }^{\circ} \mathrm{C}$ reaches $88.7 \%$ for the reference material while the decoration of the material leads to a slightly lower weight loss (close to $82.4 \%$ ). For UCALGB, the profile is very similar to the degradation path for calcium alginate [38]. A first step is detected below $155.4^{\circ} \mathrm{C}$ (maximum at 98.0 ${ }^{\circ} \mathrm{C}$ ), which is associated with water release. Several successive steps are highlighted by the DrTGA curves: $164.8^{\circ} \mathrm{C}, 212.0{ }^{\circ} \mathrm{C}, 241.0{ }^{\circ} \mathrm{C}, 284.9$ ${ }^{\circ} \mathrm{C}, 471.8^{\circ} \mathrm{C}$ and $752.9^{\circ} \mathrm{C}$. Actually, these different peaks can be ranked according to five transitions:

(a) $22.9-193{ }^{\circ} \mathrm{C}$ : water release (external and bonded) with a total loss of about $15.9 \%$.

(b) $193-336.1{ }^{\circ} \mathrm{C}$ : the weight loss for this transition reaches $38.0 \%$ and mainly corresponds to the partial depolymerization of the biopolymer and carboxylate decomposition. However, the presence of urea may involve supplementary decomposition phenomena (including amine degradation) that may explain the different wavelets (and the multiplicity of DrTGA peaks in this area).

(c) $336.1-506.4{ }^{\circ} \mathrm{C}$ : the weight loss reaches $11.3 \%$ (including $5.3 \%$ in the highest transition centered on $471.8{ }^{\circ} \mathrm{C}$ ), this corresponds to the degradation of the organic material.

(d) 506.4-722.9 ${ }^{\circ} \mathrm{C}$ : the pyrolysis of the char takes place in this temperature range and represents a weight loss close to $15.0 \%$.

(e) 722.9-785.1 ${ }^{\circ} \mathrm{C}$ : a new degradation transition is observed representing a weight loss of $8.5 \%$. Above $785{ }^{\circ} \mathrm{C}$, a plateau is observed, corresponding to the pyrolyzed char (including inorganic compounds such as calcium or chloride).

In the case of U-CALGB-MB 1.5 , the presence of the dye changes the degradation profile, the number of well-resolved peaks on the DrTGA is decreased, with three maxima at $112.1{ }^{\circ} \mathrm{C}, 211.6{ }^{\circ} \mathrm{C}$ and $353.4{ }^{\circ} \mathrm{C}$ (although some shoulders or weak peaks are also observed in the 157-250 ${ }^{\circ} \mathrm{C}$ range). These peaks are close to those observed for $\mathrm{U}$ CALGB; however, the transition centered on $357.2{ }^{\circ} \mathrm{C}$ strongly differs from the profile of U-CALGB as a specific degradation of MB or the shift of the peak centered on $471.8^{\circ} \mathrm{C}$. It is noteworthy that the dye decomposes at a temperature higher than $190{ }^{\circ} \mathrm{C}$. Another significant difference is the appearance of the positive peak at $578.5^{\circ} \mathrm{C}$, which probably corresponds to an oxidation phenomenon. In addition, the transition at $752.9^{\circ} \mathrm{C}$ disappeared and the weight loss does not change above $600{ }^{\circ} \mathrm{C}$ contrary to U-CALGB. These differences clearly show that the grafting of $\mathrm{MB}$ strongly affects the structure and thermal stability of the functionalized material. The thermal transitions are generally observed at a lower temperature than for the reference material; although the residual weight is a little higher.
Nejadebrahim et al. [39] investigated the synthesis of photosensitizers based on the formation of MB-clay nanoparticles. They observed that the TGA (and DrTGA) profiles for MB correspond to maximum degradations at $72{ }^{\circ} \mathrm{C}, 183{ }^{\circ} \mathrm{C}, 290{ }^{\circ} \mathrm{C}$ and $458{ }^{\circ} \mathrm{C}$ (which completely disappears after immobilization on clay); the immobilization of the dye on clay allows increasing the stability of the dye with maximum weight losses at $265{ }^{\circ} \mathrm{C}$ and $327^{\circ} \mathrm{C}$. For the sorbent, the identification of the degradation steps is made complex by the coexistence of different patterns of degradation associated with alginate, urea and methylene blue compounds. It is thus difficult assigning the effective amount of MB bound to the sorbent based on TGA spectrum and relevant weight loss. It is noteworthy that consistently with the conclusions raised by Nejadebrahim et al. [39], the immobilization of MB allows increasing its stability as shown by the increased values of maximum degradation temperatures (compared with pure $\mathrm{MB}$ ). The presence of $\mathrm{MB}$ also allows increasing the residual mass at $800{ }^{\circ} \mathrm{C}$ (from $11.3 \%$ to $17.6 \%$ ). The two main steps of thermal degradation of $\mathrm{MB}$ (comparing the profiles for U-CALGB and U-CALGB-MB1.5) are probably located around $212{ }^{\circ} \mathrm{C}$ (though partially superposed with the degradation steps of the raw U-CALGB) and around $353{ }^{\circ} \mathrm{C}$ (which appears to be specific to the sorbent, U-CALGB-MB1.5). The first maximum (i.e., at $212{ }^{\circ} \mathrm{C}$ ) is probably associated with the interaction between U-CALGB and MB while the second is assigned to direct degradation of MB.

\subsubsection{FT-IR}

Fig. S5 shows the FTIR spectrum of U-CALGB material. A very broad and poorly-resolved band is observed in the range $3700-3200 \mathrm{~cm}^{-1}$ with two shoulder or peaks at $3366.0 \mathrm{~cm}^{-1}$ and $3227.2 \mathrm{~cm}^{-1}$, corresponding to the contributions of $-\mathrm{OH}$ and $\mathrm{N}-\mathrm{H}$ stretching vibrations. The three small peaks at 2950.0, 2917.2 and $2849.0 \mathrm{~cm}^{-1}$ are assigned to aliphatic $\mathrm{C}-\mathrm{H}$ vibrations. The asymmetric $\mathrm{C}=\mathrm{O}$ vibration of carboxylate groups is usually observed at $1615.6 \mathrm{~cm}^{-1}$ [40]; here, the relevant peak appears at $1593.3 \mathrm{~cm}^{-1}$. The peak at $1415.9 \mathrm{~cm}^{-1}$ represents the $\mathrm{C}-\mathrm{N}$ vibration $[41,42]$. The peak at $1295.5 \mathrm{~cm}^{-1}$ is assigned to the combination of $\mathrm{C}-\mathrm{C}-\mathrm{H}$ and $\mathrm{O}-\mathrm{C}-\mathrm{H}$ deformations while the small shoulders or peaks at $1125 \mathrm{~cm}^{-1}$ and $1078.0 \mathrm{~cm}^{-1}$ are associated with $\mathrm{C}-\mathrm{O}$ stretching and $\mathrm{C}-\mathrm{O} / \mathrm{C}-\mathrm{C}$ stretching from pyranose ring. The small shoulder at $1145 \mathrm{~cm}^{-1}$ was attributed to another $\mathrm{C}-\mathrm{O}$ stretching vibration [40]. The strong peak at $1026.8 \mathrm{~cm}^{-1}$ is characteristic of $\mathrm{C}-\mathrm{O}$ stretching. The small peaks at $938.2 \mathrm{~cm}^{-1}, 886.8 \mathrm{~cm}^{-1}$ and $810.4 \mathrm{~cm}^{-1}$ are considered characteristic of alginate fingerprint; associated with $\mathrm{C}-\mathrm{O}$ stretching in uronic groups, $\mathrm{C}_{1}-\mathrm{H}$ defomation in $\beta$-mannuronic and of mannuronic acid residue, respectively. In the case of urea, Grdadolnik and Maréchal [43] reported a series of characteristic vibrations: $\mathrm{NH}_{2}$ stretching vibrations at 3437 and $3343 \mathrm{~cm}^{-1}$, CO stretching at 1599 $\mathrm{cm}^{-1}, \mathrm{NH}_{2}$ bending at 1624 and $1668 \mathrm{~cm}^{-1}$, CN stretching at 1466 and $1003 \mathrm{~cm}^{-1}, \mathrm{NH}_{2}$ rocking at 1156 and $1057 \mathrm{~cm}^{-1}$. These bands are in most cases superimposed with the characteristic bands of alginate; it makes difficult the identification of urea in the U-CALGB material. However, the absence of the peaks for $\delta\left(\mathrm{NH}_{2}\right)$ and $v(\mathrm{CN})$ vibrations tends to indicate that the binding of urea to alginate matric affects their chemical environment. It is noteworthy that the spectrum of U-CALGB is substantially different from the spectrum obtained in the case of urea and biuret alginate beads [44], where a $\mathrm{C}=\mathrm{O}$ band and a $\mathrm{CN}-$ bands were observed at $1672 \mathrm{~cm}^{-1}$ and $1459 \mathrm{~cm}^{-1}$, respectively.

In their FTIR study of MB under different phases, Ovchinnikov et al. [45] reported a series of characteristics bands correlated to specific vibrations: $v(\mathrm{ON})_{\text {bonded }}$ at $3376 \mathrm{~cm}^{-1}, \nu\left(=\mathrm{N}^{+}\left(\mathrm{CH}_{3}\right)_{2}\right)$ at $1594 \mathrm{~cm}^{-1}$, $\delta_{\text {sym }}(\mathrm{C}-\mathrm{H})$ at $1395 \mathrm{~cm}^{-1} ; \nu\left(\mathrm{C}=\mathrm{S}^{+}\right)$at $1357 \mathrm{~cm}^{-1}, \nu(\mathrm{C}-\mathrm{N})$ at $1336 \mathrm{~cm}^{-1}$. Weaker bonds have been identified at $1143 \mathrm{~cm}^{-1}$ and $1066 \mathrm{~cm}^{-1}$ for $\delta(\mathrm{C}-\mathrm{N})$ and $v(\mathrm{C}-\mathrm{S}-\mathrm{C})$, respectively. Being superposed with other signals, poorly representative peaks are also observed at $669 \mathrm{~cm}^{-1}$ and $614 \mathrm{~cm}^{-1}$ for $\nu(C-S-C)$ and $\delta(C-S-C)$, respectively. In the case of U-CALGB-MB 1.5 , the intensity of the peak at $3366 \mathrm{~cm}^{-1}$ is increased compared with U-CALGB. In addition, a wide band centered at $2138 \mathrm{~cm}^{-1}$ appears; this band may be attributed to multiple bond compounds [46]. A series of 


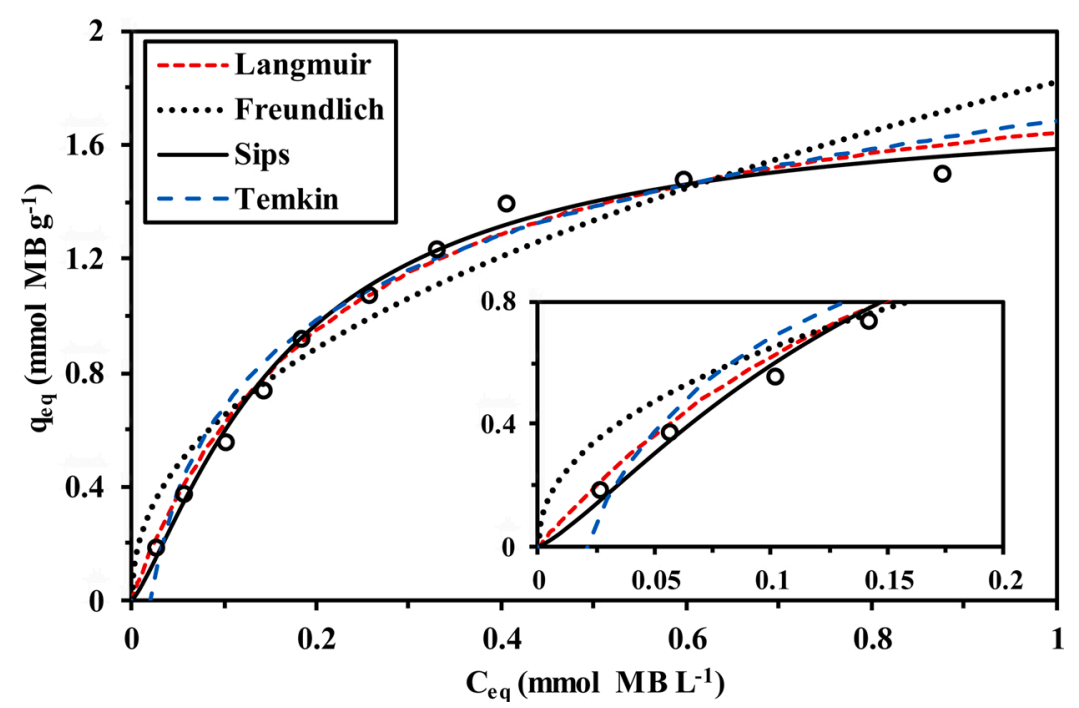

Fig. 1. $\mathrm{MB}$ sorption isotherm onto U-CALGB at $\mathrm{pH}_{0} 5.4$ (Sorbent dosage, SD: $1.5 \mathrm{~g} \mathrm{~L}^{-1}$; Agitation: $200 \mathrm{rpm}$; Time: $180 \mathrm{~min}$; $\mathrm{T}$ : $25 \pm 1{ }^{\circ} \mathrm{C}$ ).

new peaks is also detected at $1639 \mathrm{~cm}^{-1}$ (NH bending, secondary amine; or shift for stretching $\left(=\mathrm{N}^{+}\left(\mathrm{CH}_{3}\right)_{2}\right)$ bond), $1445 \mathrm{~cm}^{-1}$ (stretching $\mathrm{C}=\mathrm{C}$ bond), and $1254 \mathrm{~cm}^{-1}$ (symmetric C-N-C stretching combined with $\mathrm{C}-\mathrm{H}$ deformation), which are characteristics of thiazoline-based compounds [47]. The new peaks at $1396 \mathrm{~cm}^{-1}$ and $1389 \mathrm{~cm}^{-1}$ may be associated with the modification of the chemical environment of amine and amide groups on U-CALGB with the immobilization of MB on the support.

\subsection{5. $p H_{P Z C}$}

The surface charge of the materials has been characterized by zetametry (Fig. S6). The $\mathrm{pH}_{\mathrm{PZC}}$ slightly increases with the decoration of $\mathrm{U}$ CALGB with methylene blue from 5.54 to 6.07 . This means that the two materials are positively charged in acidic solutions (below pH 5.5-6). Independently of any chelating effects brought by the reactive groups at the surface of the sorbents, their protonation opens the route for electrostatic attraction effects.

It is noteworthy that methylene blue is known to be a redox indicator [48]; Poteet et al. [49] reported two values for the redox potentials of reactive groups on $\mathrm{MB}: 0.5 \mathrm{~V}$ and $-0.108 \mathrm{~V}$. Methylene blue is oxidized to form leucomethylene blue (colorless). Its $\mathrm{pK}_{\mathrm{a}}$ value is largely debated with data reporting $\mathrm{pK}_{\mathrm{a}}$ close to 0 [50] and up to 3.8 [51,52]. The $\mathrm{pK}_{\mathrm{a}}$ values of mannuronic and guluronic acid in chitosan have been reported close to 3.38 and 3.65, respectively [53]. On the other side, the amine groups in urea are weakly basic $\left(\mathrm{pK}_{\mathrm{a}}: 26.9\right)$.

\section{2. $M B$ sorption isotherm - Selection of $M B$ loading on $U-C A L G B-M B_{x}$}

\subsection{1. $M B$ sorption isotherm}

Methylene Blue was loaded on U-CALGB at $\mathrm{pH} 5.8$ for preparing the sorbent for $\mathrm{Cr}(\mathrm{VI})$ sorption. the selected $\mathrm{pH}$ value is close to the $\mathrm{pH}_{\mathrm{PZC}}$ of U-CALGB (i.e., 5.54) and higher than the $\mathrm{pK}_{\mathrm{a}}$ value of MB (i.e., 3.8). MB forms two mesomeric forms [54] (corresponding to double bond delocalization and alternative protonation of $\mathrm{N}$ and $\mathrm{S}$ atoms). On the other hand, its reduction into leucomethylene blue (LMB) [50] opens the way to the presence of different species such as $\mathrm{LMBH}_{3}^{2+}, \mathrm{LMBH}_{2}^{+}, \mathrm{LMHB}$ and $\mathrm{LMB}^{-}$, depending on the $\mathrm{pH}$ (corresponding to the following transitions: $\mathrm{pK}_{\mathrm{a}, \mathrm{i}}:$ 1.7, 4.5 and 5.9, respectively). At $\mathrm{pH}$ 5.8, LMBH and LMB- are almost equally distributed, while MB is deprotonated. Methylene blue sorption was also reported to be optimum at $\mathrm{pH}$ higher than 6 using starch/polyacrylamide sorbent [55], or 5.5 for dextran sulfate/polyacrylamide [56]. Fig. 1 shows MB sorption isotherm on U-CALGB: the maximum sorption capacity is close to $480 \mathrm{mg} \mathrm{g}^{-1}$ (i.e., $1.5 \mathrm{mmol} \mathrm{MB}$ $\mathrm{g}^{-1}$ ). This value is consistent with the results reported for starch/PAA (i. e. $327 \mathrm{mg} \mathrm{g}^{-1}$ ); however, after hydrolysis, the sorption capacity
Table 1

MB sorption isotherm onto U-CALGB - Parameters of the models.

\begin{tabular}{lllll}
\hline Model & Parameter & & $\mathrm{R}^{2}$ & AIC \\
\hline Experimental & $\mathrm{q}_{\mathrm{m}, \exp }\left(\mathrm{mmol} \mathrm{g}^{-1}\right)$ & 1.50 & & \\
Langmuir & $\mathrm{q}_{\mathrm{m}, \mathrm{L}}\left(\mathrm{mmol} \mathrm{g}^{-1}\right)$ & 2.01 & 0.989 & -59.1 \\
& $\mathrm{~b}_{\mathrm{L}}\left(\mathrm{L} \mathrm{mmol}^{-1}\right)$ & 4.46 & & \\
Freundlich & $\mathrm{k}_{\mathrm{F}}$ & 1.82 & 0.943 & -40.8 \\
& $\mathrm{n}_{\mathrm{F}}$ & 2.23 & & \\
\multirow{2}{*}{ Sips } & $\mathrm{q}_{\mathrm{m}, \mathrm{S}}\left(\mathrm{mmol} \mathrm{g}^{-1}\right)$ & 1.75 & & -61.3 \\
& $\mathrm{~b}_{\mathrm{S}}\left(\mathrm{L} \mathrm{mmol}^{-1}\right)$ & 9.92 & 0.994 & \\
\multirow{2}{*}{ Temkin } & $\mathrm{n}_{\mathrm{S}}$ & 0.776 & & -50.6 \\
& $\mathrm{~B}_{\mathrm{T}}\left(\mathrm{J} \mathrm{mol}^{-1}\right)$ & 5692 & 0.977 & \\
\hline
\end{tabular}

increased up to $639 \mathrm{mg} \mathrm{g}^{-1}$ [55]. With Gelidium algal-based materials (agar-rich biomass), Vilar et al. [57] reported maximum sorption capacity close to $171 \mathrm{mg} \mathrm{g}^{-1}$ (i.e., $0.54 \mathrm{mmol} \mathrm{MB}^{-1}$ ). In the case of magnetic rice husk/alginate composite, the sorption capacity reached $275 \mathrm{mg} \mathrm{g}^{-1}$ at pH 6 [58]. Alver et al. [58] compared the sorption capacities of a series of alginate-based sorbents: sorption capacities ranged between $17 \mathrm{mg} \mathrm{g}^{-1}$ up to $906 \mathrm{mg} \mathrm{g}^{-1}$ : the most efficient sorbents consisted of the association of alginate with activated carbon, multiwalled carbon nanotubes. The current sorbent (i.e., U-CALGB) shows maximum sorption capacity immediately below the performance of these highperforming materials, but much higher than most of these alginate-based sorbents.

In Fig. 1, the experimental data are fitted with a series of conventional equations. Table 1 reports the parameters of these models (together with the relevant determination coefficients and the Akaike Information Criterion). The power-like empirical Freundlich equation is not appropriate for simulating the saturation profile of the isotherm. The comparison of the statistical criteria also confirms that the Temkin equation fails to fit experimental data in low and high concentration ranges. The Langmuir (mechanistic) equation that supposes the sorption to proceed as a monolayer without interactions between sorbent molecules (with homogeneous energy distribution) is comparable to the empirical Sips equation (which combines Langmuir and Freundlich equations). The Sips equation slightly improves the quality of the fit at low MB concentration; however, the Langmuir equation offers a good compromise in the physical and chemical interpretation and the mathematical quality of the modeling of experimental profile.

\subsubsection{Selection of $M B$ loading on UCALGB-MB $B_{x}$ for $\operatorname{Cr}(V I)$ sorption}

The next step in the design of the sorbent consisted of optimizing MB 


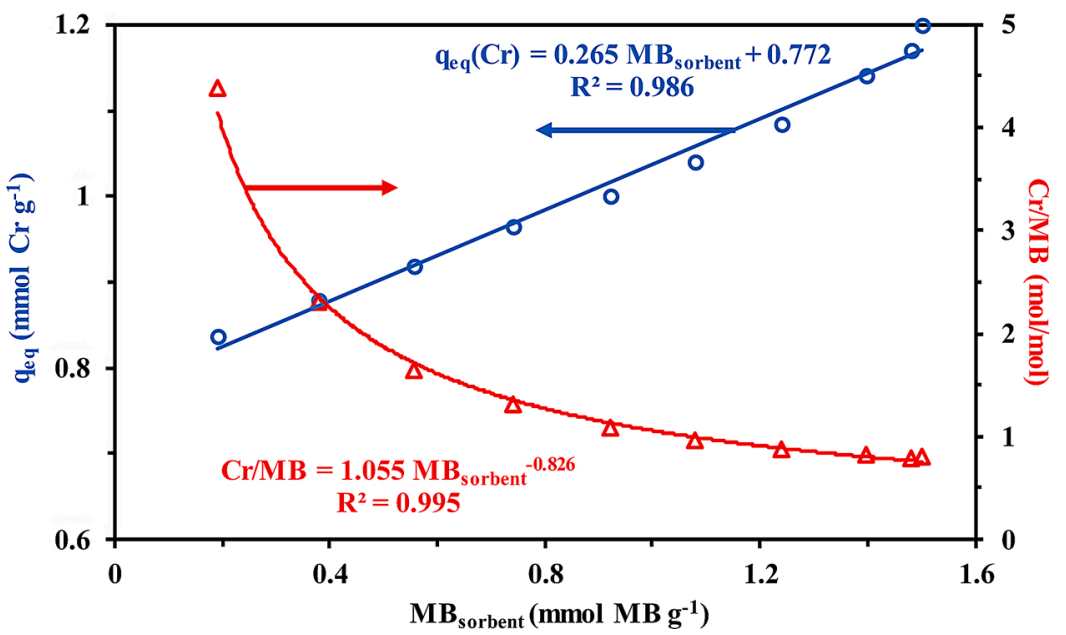

Fig. 2. Effect of MB-loading on $\mathrm{Cr}(\mathrm{VI})$ sorption onto U-CALGB-MB $\mathrm{x}_{\mathrm{x}}$ and molar ratio $\mathrm{Cr} / \mathrm{MB}\left(\mathrm{pH}_{0} 3 ; \mathrm{C}_{0}: 1.923 \mathrm{Cr} \mathrm{L}^{-1}\right.$; Sorbent dosage, SD: $1.5 \mathrm{~g} \mathrm{~L}{ }^{-1}$; Agitation: 200 $\mathrm{rpm}$; Time: $90 \mathrm{~min}$; $\left.\mathrm{T}: 25 \pm 1^{\circ} \mathrm{C}\right)$.

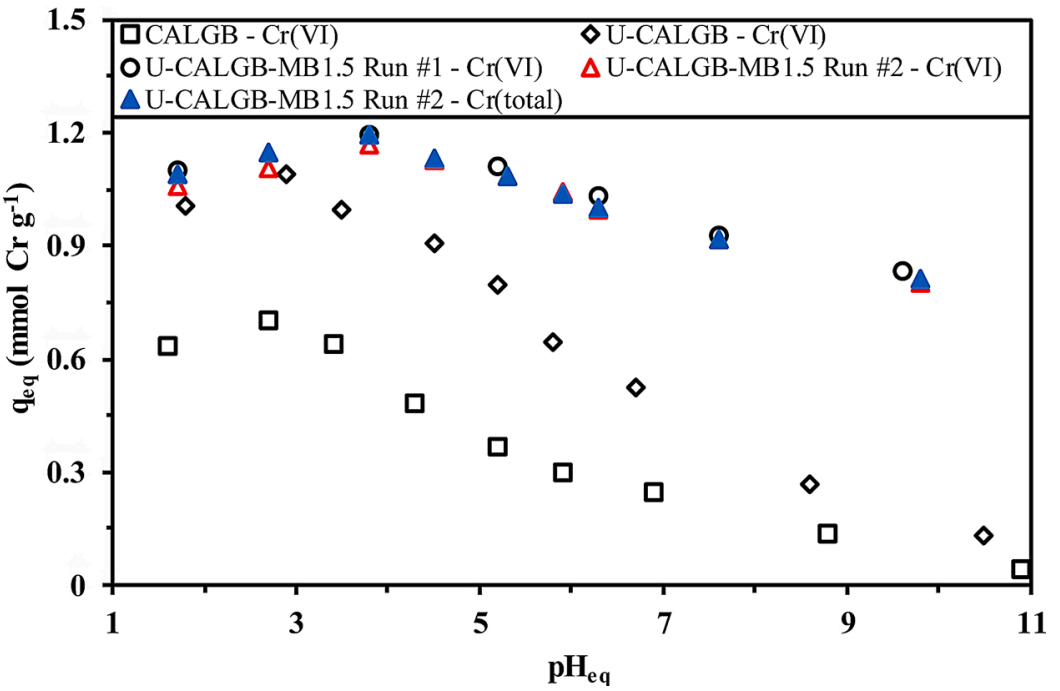

Fig. 3. Effect of $\mathrm{pH}$ on $\mathrm{Cr}(\mathrm{VI})$ sorption onto CALGB, U-CALGB and U-CALGB-MB $1.5\left(\mathrm{C}_{0}: 1.923 \mathrm{Cr} \mathrm{L}^{-1}\right.$; Sorbent dosage, SD: $1.5 \mathrm{~g} \mathrm{~L}{ }^{-1}$; Agitation: $200 \mathrm{rpm}$; Time: 90 min; T: $25 \pm 1{ }^{\circ} \mathrm{C}$; including comparison of $\mathrm{Cr}(\mathrm{VI}) / \mathrm{Cr}$ (total) sorption for U-CALGB-MB ${ }_{1.5}$ ).

loading on U-CALGB for the specific purpose of chromate sorption. The samples collected in the sorption isotherm of MB on U-CALGB were used for comparing $\mathrm{Cr}(\mathrm{VI})$ sorption capacity under comparable experimental conditions. Fig. 2 shows the effect of MB loading on the sorbent $(\mathrm{x}, \mathrm{mmol}$ $\mathrm{MB} \mathrm{g}^{-1}$ in U-CALGB-MB $\mathrm{x}$ ) on the sorption capacity for $\mathrm{Cr}(\mathrm{VI})$ at $\mathrm{pH} 3$ and the molar ratio $\mathrm{Cr}(\mathrm{VI}) / \mathrm{MB}$ ( $\mathrm{mol} / \mathrm{mol})$. The sorption capacity linearly increases with MB loading, at least in the tested range of loadings. The slope of the curve is close to 0.265 ; meaning that about $4 \mathrm{~mol}$ of $\mathrm{MB}$ are necessary for the removal of $1 \mathrm{~mol} \mathrm{Cr}(\mathrm{VI})$ (i.e., 3.77). The effective molar ratio $\mathrm{Cr} / \mathrm{MB}$ decreases with $\mathrm{MB}$ loading from 4.38 to 0.80 with the increase in MB loading (following a power-like function): the last section of the curve is almost linear between 0.92 and $1.5 \mathrm{mmol} \mathrm{MB} \mathrm{g}^{-1}$ loadings. Fig. S7 shows the linear variations of the sorption capacity for $\mathrm{Cr}$ (VI) (in the range $0.84-1.2 \mathrm{mmol} \mathrm{Cr} \mathrm{g}^{-1}$ ) and the sorption efficiency (in the range $65.2-93.5 \%$ ) with the concentration of the MB used in the impregnation batch (see Section 3.2.1.). The highest $\mathrm{Cr}(\mathrm{VI})$ sorption capacity is obtained with the highest MB concentration in the solution and on the sorbent. The effective MB loading for further sorption tests is set at $1.5 \mathrm{mmol} \mathrm{MB} \mathrm{g}^{-1}$, taking into account only the absolute sorption capacity. Actually, the sorption efficiency for MB (Fig. S7) decreases, as expected, with $\mathrm{MB}$ concentration in the impregnation bath; however, the loss in the dyes increases more substantially above $\mathrm{MB}_{0}: 2.5 \mathrm{mmol}$ $\mathrm{MB} \mathrm{L}^{-1}$ (i.e., for MB loading corresponding to $1.4 \mathrm{mmol} \mathrm{MB}^{-1}$ ). Taking into account the limited enhancement in $\mathrm{Cr}(\mathrm{VI})$ sorption capacity (from $1.14 \mathrm{mmol} \mathrm{Cr} \mathrm{g}^{-1}$ to $1.20 \mathrm{mmol} \mathrm{Cr} \mathrm{g}^{-1}$ ), with increasing $\mathrm{MB}$ loading, better rational use of $\mathrm{MB}$ would be probably reached limiting $\mathrm{MB}$ loading to $1.14 \mathrm{mmol} \mathrm{MB} \mathrm{g}^{-1}$. Under these conditions, $\mathrm{MB}$ initial concentration in the solution close to $1.4 \mathrm{mmol} \mathrm{MB} \mathrm{L}^{-1}$, the residual concentration would be close to $0.4 \mathrm{mmol} \mathrm{MB} \mathrm{L}{ }^{-1}$ (contrary to $0.88 \mathrm{mmol}$ $\mathrm{MB} \mathrm{L}^{-1}$ at the highest MB loading).

\section{3. $\operatorname{Cr}(V I)$ sorption}

\subsection{1. $p H$ effect}

Fig. 3 compares the effect of equilibrium $\mathrm{pH}$ on the sorption of $\mathrm{Cr}(\mathrm{VI})$ using as-produce CALGB, U-CALGB and U-CALGB-MB ${ }_{1.5}$ beads in order to evaluate the respective contribution of alginate, urea-alginate and MB-functionalized sorbent. The three profiles show the same trends whereas the $\mathrm{pH}$ increases: in acidic solutions, the sorption capacity increases up to a maximum reached at $\mathrm{pH} 2.7$ for CALGB, 2.9 for U-CALGB and 3.8 for $\mathrm{U}$-CAlGB-MB $\mathrm{M}_{1.5}$. Above these respective $\mathrm{pH}$ values, the sorption capacities decrease. The successive modifications of the sorbent 


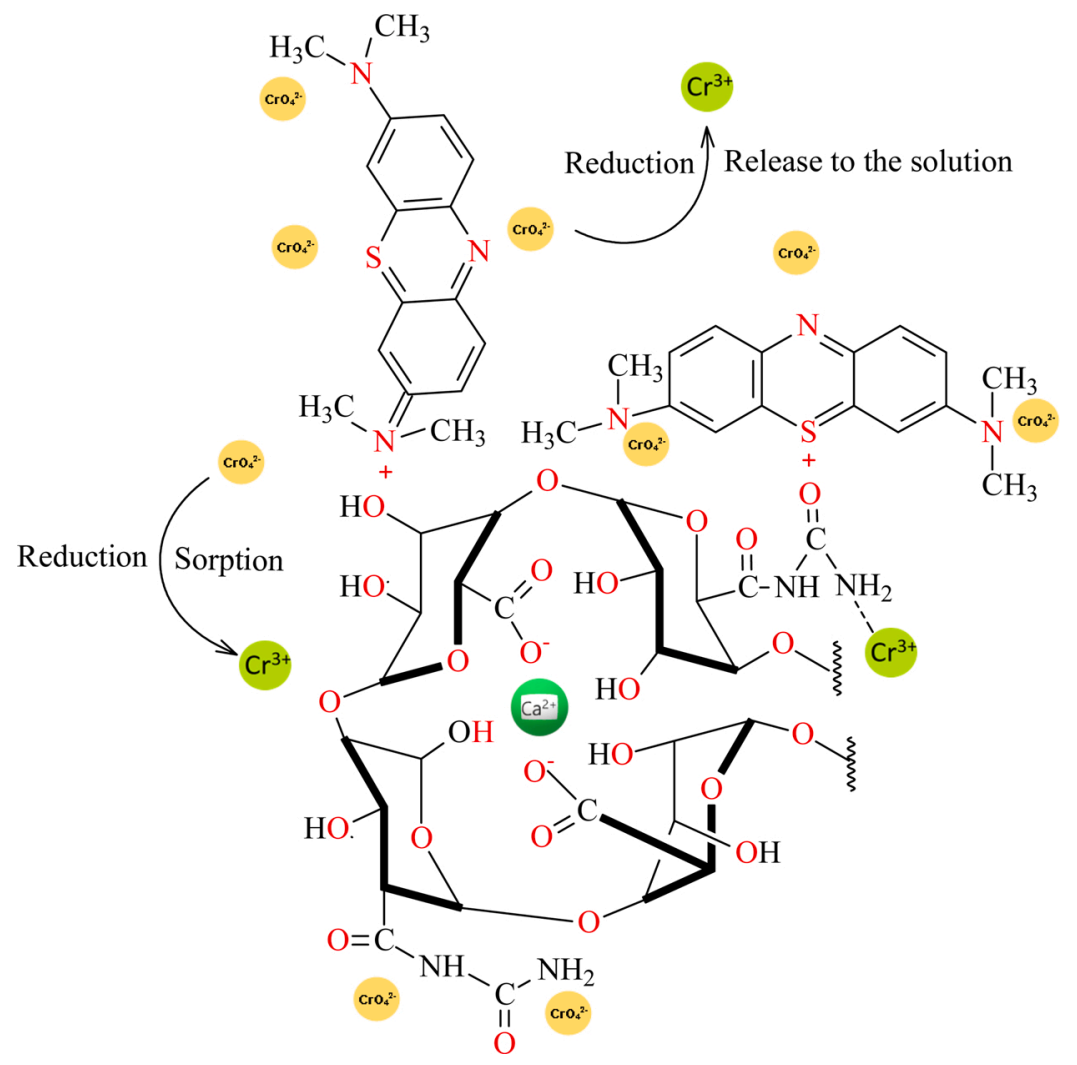

Scheme 2. Suggested modes of interactions of chromate with U-CALGB-MB 1.5 .

cause a double shift; in terms of both optimum $\mathrm{pH}$ and sorption capacities. This is a clear evidence that the chemical modifications of the raw material are substantially enhancing the sorption capacity of the sorbent for $\mathrm{Cr}(\mathrm{VI})$ but also changing the response of the sorbent toward the $\mathrm{pH}$ : the acid-base properties of the sorbents are modified by the presence of additional reactive groups. This is also the first justification for the functionalization of raw calcium alginate beads.

For U-CALGB-MB ${ }_{1.5}$, the superposition of the two runs (duplicate experiments) confirms the good reproducibility of sorption performance. In the case of Run \#2, the solutions were analyzed for both $\mathrm{Cr}$ (VI) (5-diphenylcarbazine colorimetric method) and $\mathrm{Cr}$ (total) (ICP-MS method) in order to evaluate the possible contribution of reduction phenomenon on the removal of $\mathrm{Cr}(\mathrm{VI})$. At $\mathrm{pH}>4$, the concentrations of $\mathrm{Cr}(\mathrm{VI})$ and $\mathrm{Cr}$ (total) in the solution are not significantly different and the removal of $\mathrm{Cr}(\mathrm{VI})$ proceeds uniquely through chromate sorption. At $\mathrm{pH}$ $<4$, a weak difference in the residual concentrations is observed; this means that a fraction of chromate that disappears is actually converted into $\mathrm{Cr}(\mathrm{III})$. The reduction of $\mathrm{Cr}(\mathrm{VI})$ in acidic solutions in the presence of organic matter is well established [59-65]. Park et al. [61] reported a convincing description of the reduction-assisted sorption mechanism for $\mathrm{Cr}(\mathrm{VI})$ recovery from aqueous solutions by biosorption. They propose two mechanisms involving:

(a) the direct reduction of chromate to $\mathrm{Cr}$ (III) in the aqueous solution due to electron-donor groups present at the surface of the sorbent, followed by the complexation of Cr(III) species on the sorbent (or released as $\mathrm{Cr}$ (III) in the solution).

(b) the sorption of chromate on cationic reactive groups (though electrostatic attraction or ion-exchange), followed by the in situ reduction of chromate to $\mathrm{Cr}(\mathrm{III})$ on adjacent electron-donor reactive groups. Finally, $\mathrm{Cr}(\mathrm{III})$ ions may be released or bound to reactive groups having an affinity for metal cations.

Herein, the weak difference in the concentrations of $\mathrm{Cr}(\mathrm{VI})$ and $\mathrm{Cr}$ (total) in the solutions (less than 3\%) means that the fraction released in the solution is negligible. The abatement of $\mathrm{Cr}(\mathrm{VI})$ concentration is mainly operating at the surface of the sorbent; under the form of $\mathrm{Cr}(\mathrm{VI})$ binding probably through electrostatic attraction and possibly under the form of $\mathrm{Cr}(\mathrm{III})$.

The sorption (associated with reduction phenomenon) is enhanced with the $\mathrm{pH}$ increase up to $\mathrm{pH}_{\mathrm{eq}} 3.8$ (i.e., $\mathrm{pH}_{0}$ : 3): sorption capacity increases from 1 to $1.1 \mathrm{mmol} \mathrm{Cr} \mathrm{g}^{-1}$ to $1.14-1.2 \mathrm{mmol} \mathrm{Cr} \mathrm{g}^{-1}$. Above this limit $\mathrm{pH}$ value, the sorption capacity progressively and linearly de-

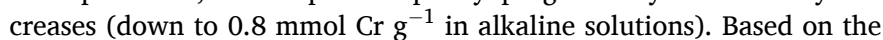
$\mathrm{pH}_{\text {PZC }}$ of the sorbent (U-CALGB-MB ${ }_{1.5}$, i.e., 6.07), the sorbent may readily bind metal anions through electrostatic attraction or ionexchange of counter anions bound to protonated amine groups on the sorbent. Fig. S8a shows the speciation diagram of $\mathrm{Cr}(\mathrm{VI})$. Regardless of the $\mathrm{pH}, \mathrm{Cr}(\mathrm{VI})$ is present under anionic forms: $\mathrm{HCrO}_{4}$ - predominates below pH 4 (with the presence of $\mathrm{Cr}_{2} \mathrm{O}_{7}^{2-}$, representing less than $13 \%$ ), while $\mathrm{CrO}_{4}^{2-}$ is predominant above. All these species may be readily bound below $\mathrm{pH}_{\mathrm{PZC}}$ on protonated reactive groups (amine groups, protonated charges of $\mathrm{MB}$ ). In strongly acidic conditions, the competitive presence of the counter anions may limit the binding of chromate species, with the $\mathrm{pH}$ increase this competitor effect decreases. Another explanation for the lower sorption in very acidic solutions may be associated with the release of $\mathrm{MB}$ in the solution at $\mathrm{pH}$ below 3 (Table S3). The release of the dyes may have two adverse effects: (a) the decrease in the density of sorption sites on the sorbent, and (b) the competitive effect of free dyes in the solution for reacting with chromate species (in terms of binding and reduction), this release decreases with increasing the $\mathrm{pH}$. Above $\mathrm{pH} 3.8$, the sorption capacity tends to decrease. This inversion may be correlated to the appearance of $\mathrm{CrO}_{4}^{2-}$, the progressive decrease of $\mathrm{HCrO}_{4}$ - (which is probably the preferentially bound species). However, this is more probably associated with the progressive deprotonation of MB (pKa: 3.8). The diminution of the density of protonated reactive groups causes the decrease in sorption capacities. However, the sorption remains relatively high even under $\mathrm{pH}$ 


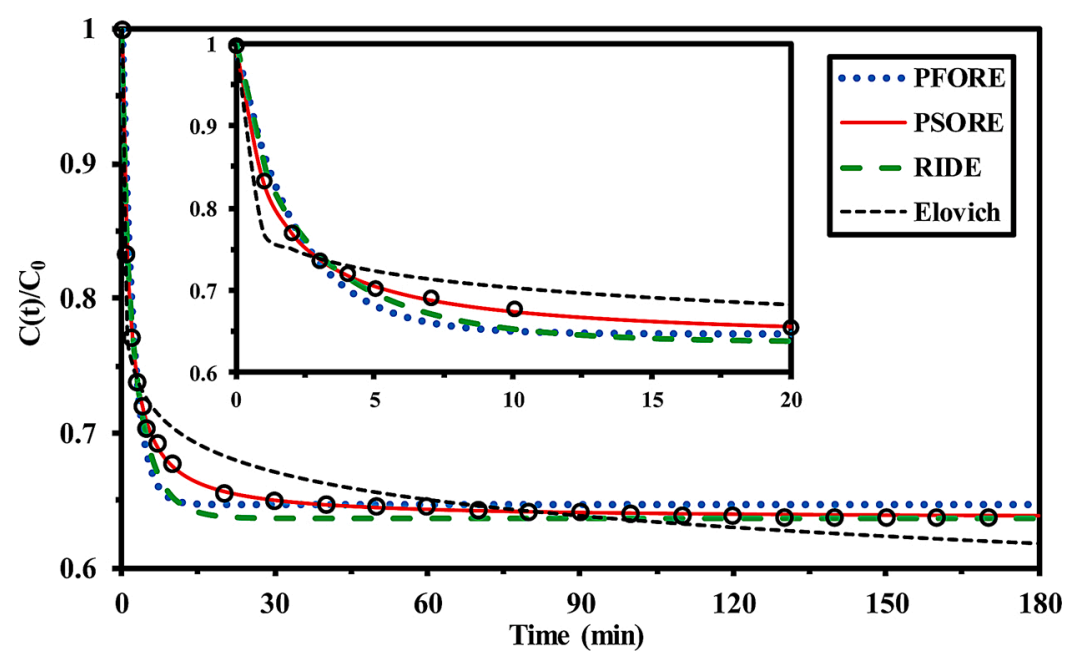

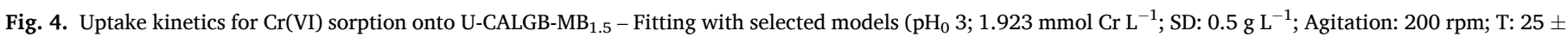
$\left.1{ }^{\circ} \mathrm{C}\right)$.

conditions where MB is totally deprotonated. It means that secondary phenomena may be involved in the abatement of $\mathrm{Cr}(\mathrm{VI})$ such as the reduction of $\mathrm{Cr}(\mathrm{VI})$ into $\mathrm{Cr}(\mathrm{III})$ followed by binding on anionic reactive groups (carboxylate groups are formed above $\mathrm{pK}_{\mathrm{a}}$ of uronic acids of alginate; i.e., 3.38 and 3.65), amine groups of urea or in situ precipitation of $\mathrm{Cr}(\mathrm{III})$. Fig. $\mathrm{S} 9$ reports the speciation diagram of $\mathrm{Cr}$ (III) that shows the occurrence of precipitation at $\mathrm{pH}>4.41$. This mix of binding mechanisms may explain that sorption capacity remains quite high $(0.8 \mathrm{mmol}$ $\mathrm{Cr} \mathrm{g}^{-1}$ ) even at $\mathrm{pH}$ higher than 11 .

Fig. S10 shows the changes in the ORP of the solutions as a function of the $\mathrm{pH}$ : the potential of the initial solution is not affected by the $\mathrm{pH}$ (i. e., $1.416 \pm 0.034 \mathrm{~V}$ ). After $\mathrm{Cr}(\mathrm{VI})$ sorption, the redox potential strongly reduces as a confirmation of the occurrence of redox phenomena (around $0.7 \mathrm{~V}$ in the $\mathrm{pH}_{0}$ range 1-3). The ORP variation progressively decreases with increasing the $\mathrm{pH}$.

Fig. S11a shows $\mathrm{pH}$ variation during the sorption of $\mathrm{Cr}(\mathrm{VI})$. The $\mathrm{pH}$ tends to increase in the range $\mathrm{pH}_{0} 1-5$ and to decrease above $\mathrm{pH}_{0} 5$. This is roughly consistent with the evolution of zeta potential (for metal-free solutions, Fig. S6). It is noteworthy that for CALGB and U-CALGB the $\mathrm{pH}$ variations are much less marked: the lower sorption of chromate may explain this higher $\mathrm{pH}$ stability. This may be also explained by the increased effect of MB on the dye-functionalized sorbent (proper acidbased properties of MB moieties). Fig. S11b shows the changes of the distribution ratio $\mathrm{D}\left(\mathrm{D}=\mathrm{q}_{\mathrm{eq}} / \mathrm{C}_{\mathrm{eq}}, \mathrm{L} \mathrm{g}^{-1}\right.$ ) with the equilibrium $\mathrm{pH}$. The slopes, frequently associated with the stoichiometric ratio of proton exchange in ion-exchange processes, are symmetrical $(+0.19 /-0.19)$ around $\mathrm{pH}_{\mathrm{eq}}$ 3.8. The value of these slopes is not consistent with possible stoichiometry in ion-exchange reactions between chromates species present in the solution and the protonated reactive groups on the sorbent. In Section 3.2.2., the stoichiometric ratio between $\mathrm{Cr}(\mathrm{VI})$ and $\mathrm{MB}$ was found close to 0.265 (here around 0.19 ). The complexity and

Table 2

Uptake kinetics for $\mathrm{Cr}(\mathrm{VI})$ sorption onto U-CALGB-MB ${ }_{1.5}$ - Parameters of the models.

\begin{tabular}{lllll}
\hline Model & Parameter & & $\mathrm{R}^{2}$ & AIC \\
\hline Experimental & $\mathrm{q}_{\mathrm{m}, \exp }\left(\mathrm{mmol} \mathrm{g}^{-1}\right)$ & 1.396 & & \\
PFORE & $\mathrm{q}_{\mathrm{m}, 1}\left(\mathrm{mmol} \mathrm{g}^{-1}\right)$ & 1.360 & 0.972 & -191 \\
& $\mathrm{k}_{1}\left(\mathrm{~min}^{-1}\right)$ & 0.462 & & \\
PSORE & $\mathrm{q}_{\mathrm{m}, 2}\left(\mathrm{mmol} \mathrm{g}^{-1}\right)$ & 1.401 & 0.999 & -294 \\
& $\mathrm{k}_{2}\left(\mathrm{~g} \mathrm{mmol}^{-1} \mathrm{~min}^{-1}\right)$ & 0.601 & & \\
Elovich & $\alpha\left(\mathrm{mmol} \mathrm{g}^{-1} \mathrm{~min}^{-1}\right)$ & 247.1 & 0.948 & -178 \\
RIDE & $\beta\left(\mathrm{mmol} \mathrm{g}^{-1}\right)$ & 8.764 & & -206 \\
\hline
\end{tabular}

diversity of the mechanisms involved in metal binding may explain these unexpected results. For CALG, the general shape of the curve is respected but the slopes of the two segments are flatten (+0.08/-0.17). In the case of U-CALGB, the first segment shows a comparable slope with MB (functionalized sorbent (i.e., +0.18 ) while the second segment is a little steeper (i.e., -23.5). This is consistent with the comparison of the pH-edges for the sorption capacities of the different sorbents (Fig. 3).

The effect of $\mathrm{pH}$ on metal sorption, the acid-base properties (overall ionic charge and $\mathrm{pH}_{\mathrm{PZC}}$ ) the specific redox properties of both chromate anions and MB-based support open many possibilities for describing the interactions of U-CALGB-MB ${ }_{1.5}$ with chromate. These mechanisms are summarized in Scheme 2.

\subsubsection{Effect of sorbent dosage (SD)}

Fig. S12 shows the effect of sorbent dosage on the sorption capacity and sorption efficiency for $\mathrm{Cr}(\mathrm{VI})$ removal at $\mathrm{pH}$ 3. As expected, increasing the dosage of sorbent increases the efficiency of metal removal. However, the differences are relatively limited: with a SD of $0.5 \mathrm{~g} \mathrm{~L}^{-1}$, the sorption efficiency reaches $90.5 \%$; at SD values of $4.5-5 \mathrm{~g}$ $\mathrm{L}^{-1}$, the sorption efficiency does not exceed $96 \%$. A tenfold increase in sorbent dosage increases by only $5 \%$ the sorption efficiency. Obviously, high SD values do not allow a rationale use of sorption reactive groups on the sorbent. This is confirmed by the strong decrease in the relevant sorption capacities that decrease from $3.48 \mathrm{mmol} \mathrm{Cr} \mathrm{g}^{-1}$ to $0.37 \mathrm{mmol}$ $\mathrm{Cr} \mathrm{g}^{-1}$. A sorbent dosage of $1.5 \mathrm{~g} \mathrm{~L}^{-1}$ is selected for the next studies.

\subsubsection{Uptake kinetics}

3.3.3.1. Effect of stirring speed on $\mathrm{Cr}(V I)$ sorption. Uptake kinetics may be controlled by different mechanisms including the proper reaction rate (frequently described by pseudo-first order reaction rate, PFORE, or the pseudo-second order reaction rate, PSORE) and resistance to diffusion (external diffusion and/or intraparticle diffusion, RIDE). The resistance to external diffusion is frequently predominant in the very first minutes of contact before resistance to intraparticle plays a dominant role in the overall control of uptake kinetics. Usually, a good way to reduce the impact of the resistance to external diffusion consists of increasing the agitation speed to reduce the thickness of the external film surrounding the particles. Fig. S13 compares $\mathrm{Cr}(\mathrm{VI})$ sorption capacities reached after 90 min of contact for different agitation speeds. Though this curve cannot be correlated to kinetic profiles, these data clearly demonstrate the increase in chromate sorption with increasing the agitation of the solution; however, this beneficial effect becomes negligible when the agitation speed reaches $200 \mathrm{rpm}$. This velocity of agitation is selected for 


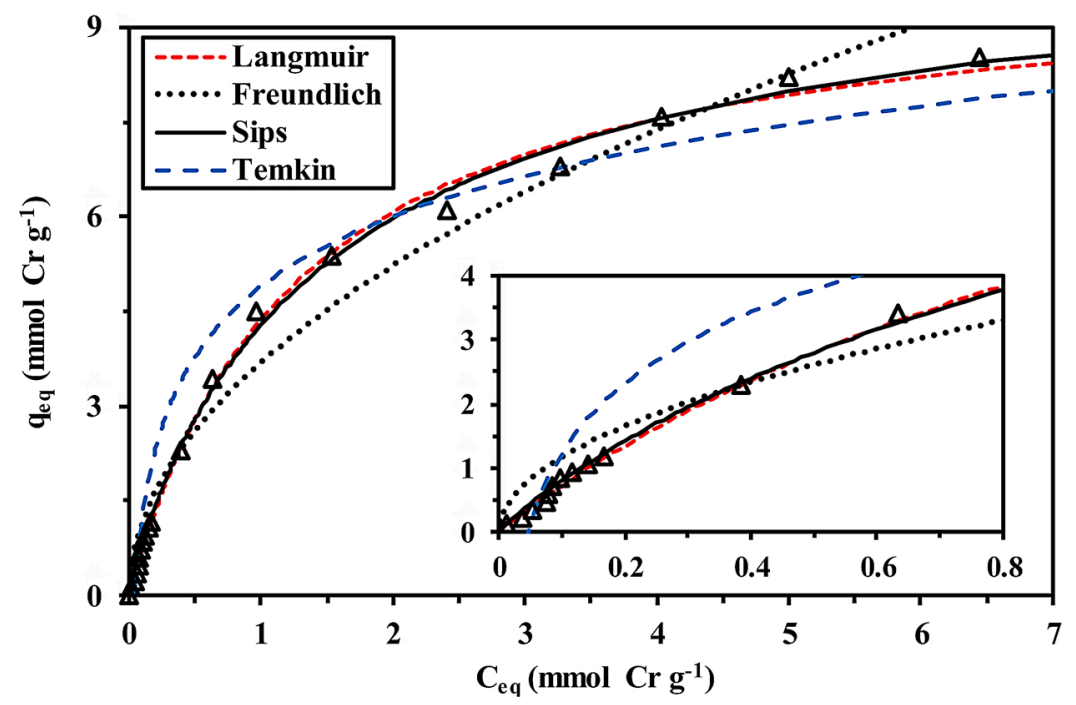

Fig. 5. $\mathrm{Cr}(\mathrm{VI})$ sorption isotherm using U-CALGB-MB 1.5 - Fitting with selected models $\left(\mathrm{pH}_{0}\right.$ 3; $\mathrm{C}_{0}$ : 0.192-19.2 mmol Cr L ${ }^{-1}$; SD: $1.5 \mathrm{~g} \mathrm{~L}^{-1}$; Agitation: $200 \mathrm{rpm}$; Time: 90 min; $\mathrm{T}: 25 \pm 1{ }^{\circ} \mathrm{C}$ ).

further experiments in order to minimize the contribution of resistance to film diffusion.

3.3.3.2. Kinetic profiles. Fig. 4 shows the kinetic profile of $\mathrm{Cr}(\mathrm{VI})$ sorption at $\mathrm{pH}_{0} 3\left(\mathrm{pH}_{\mathrm{eq}}: 3.8\right)$ with a sorbent dosage of $1.5 \mathrm{~g} \mathrm{~L}^{-1}$. Under selected experimental conditions, the sorption is relatively fast: equilibrium is reached within $20-30 \mathrm{~min}$, despite the large size of the beads (average: $3.17 \mathrm{~mm}$ ). The modeling of the kinetic profiles is compared in Fig. 4 and Table 2 using the PFORE, the PSORE, the RIDE and the Elovich equations (Table S1a). The figure clearly demonstrates that the best model for fitting the kinetic profile is the PSORE, especially for describing the zone of highest curvature. This is confirmed by the comparison of the determination coefficients, and by the AIC values. In addition, in the case of PFORE and PSORE comparison, the value of the equilibrium sorption capacity is closer for PSORE (i.e., $1.401 \mathrm{mmol} \mathrm{Cr}$ $\mathrm{g}^{-1}$ ) to the experimental value (i.e., $1.396 \mathrm{mmol} \mathrm{Cr}^{-1}$ ) compared with PFORE (i.e., $1.360 \mathrm{mmol} \mathrm{Cr}^{-1}$ ). The apparent rate coefficient $\mathrm{k}_{2}$ (for PSORE) is close to $0.601 \mathrm{~g} \mathrm{mmol}^{-1} \mathrm{~min}^{-1}$. The PSORE is frequently associated with chemisorption; meaning that the sorption occurs through sharing or exchanging electrons (valence force) between the sorbent and metal ions. However, Hubbe et al. [66] recently discussed the inappropriate interpretation driven by the misuse of the PSORE. Very strict conditions are supposed to be fulfilled (limited variation of solution concentration, for example) for really assigning the control of the kinetics to chemisorption. Alternatively, they conclude that the PSORE inappropriately applied should be rather correlated to resistance to intraparticle diffusion. The Crank equation (i.e., RIDE) gives a relatively good fit of experimental profile (at least compared to Elovich equation, and even PFORE); although the zone of highest curvature is poorly fitted. The effective diffusivity is found close to $1.69 \times 10^{-7} \mathrm{~m}^{2}$ $\mathrm{min}^{-1}$. This is relatively high, even higher than the value reported for self-diffusion of chromate ions into water (i.e., $0.68 \times 10^{-7} \mathrm{~m}^{2} \mathrm{~min}^{-1}$, [67]). This discrepancy clearly demonstrates that the RIDE does not give an appropriate modeling of kinetic profile; but the elevated higher of magnitude of this effective diffusion coefficient indicates that the material has relatively good diffusion properties. Another possible explanation for this difficulty in modeling may be assigned to the contribution of different mechanisms involving both sorption and reduction phenomena.

\subsubsection{Sorption isotherm}

The equilibrium distribution of chromate between sorbent and solution phase for different metal concentrations at $\mathrm{pH}_{0} 3$ is reported on
Table 3

$\mathrm{Cr}(\mathrm{VI})$ sorption isotherm onto U-CALGB-MB ${ }_{1.5}$ - Parameters of the models.

\begin{tabular}{lllll}
\hline Model & Parameter & & $\mathrm{R}^{2}$ & AIC \\
\hline Experimental & $\mathrm{q}_{\mathrm{m}, \text { exp }}\left(\mathrm{mmol} \mathrm{g}^{-1}\right)$ & 8.53 & & \\
Langmuir & $\mathrm{q}_{\mathrm{m}, \mathrm{L}}\left(\mathrm{mmol} \mathrm{g}^{-1}\right)$ & 9.96 & 0.997 & -67.5 \\
& $\mathrm{~b}_{\mathrm{L}}\left(\mathrm{Lmol}^{-1}\right)$ & 0.78 & & \\
\multirow{2}{*}{ Freundlich } & $\mathrm{k}_{\mathrm{F}}$ & 3.69 & 0.979 & -26.8 \\
& $\mathrm{n}_{\mathrm{F}}$ & 2.00 & & \\
\multirow{3}{*}{ Sips } & $\mathrm{q}_{\mathrm{m}, \mathrm{S}}\left(\mathrm{mmol} \mathrm{g}^{-1}\right)$ & 10.76 & & \\
& $\mathrm{~b}_{\mathrm{S}}\left(\mathrm{L} \mathrm{mmol}^{-1}\right)$ & 0.66 & 0.998 & -68.9 \\
\multirow{3}{*}{ Temkin } & $\mathrm{n}_{\mathrm{S}}$ & 1.10 & & \\
& $\mathrm{~B}_{\mathrm{T}}\left(\mathrm{J} \mathrm{mol}^{-1}\right)$ & 1553 & 0.945 & -9.70 \\
\hline
\end{tabular}

sorption isotherm (Fig. 5). The curve is characterized by a saturation plateau: the saturation is progressive and it is necessary to reach a relatively high metal concentration (i.e., about $5 \mathrm{mmol} \mathrm{Cr} \mathrm{g}^{-1}$ ) to reach the pseudo-plateau. This is also correlated to a weak initial slope. These two observations demonstrate that despite the high sorption capacities (the saturation plateau is set at $8.53 \mathrm{mmol} \mathrm{Cr} \mathrm{g}^{-1}$ ) the sorbent has a weak affinity for $\mathrm{Cr}(\mathrm{VI})$ (affinity proportional to this initial slope according to the Langmuir isotherm). Fig. S8b shows the speciation diagram of chromate under selected experimental conditions for sorption isotherms: with increasing metal concentration, the fraction of $\mathrm{HCrO}_{4}$ tends to decrease while that of $\mathrm{Cr}_{2} \mathrm{O}_{7}^{2-}$ increases. It may contribute to the progressive stabilization of sorption capacity. However, the most important reason is obviously associated with the progressive saturation of sorption sites. The combination of weak affinity and high sorption capacity can probably be explained by the conjunction of different interaction modes that concomitantly or successively contribute to metal binding: ion-exchange/electrostatic attraction, chelation, reduction of chromate, and possible in situ precipitation of $\mathrm{Cr}(\mathrm{III})$. The saturation is reached around $8.53 \mathrm{mmol} \mathrm{Cr} \mathrm{g}^{-1}$, the molar ratio $\mathrm{Cr} / \mathrm{MB}$ is then close to 5.7. This is another evidence that it is not possible setting a clear stoichiometric ratio based on a simple ion-exchange interactions and/or chelation. Secondary phenomena influence this molar ratio through reduction, in situ precipitation or direct sorption on alternative reactive groups.

The sorption isotherms have been modelled using Langmuir, Freundlich, Sips and Temkin equations (Table S1b). Fig. 5 shows the superposition of experimental points and fitted curves (including the initial section of the isotherm). Table 3 reports the parameters of the different models (together with the statistical evaluation of the 
Table 4

Comparison of $\mathrm{Cr}(\mathrm{VI})$ sorption capacities with conventional sorbents.

\begin{tabular}{|c|c|c|c|c|c|}
\hline Sorbent & $\mathrm{pH}$ & $\begin{array}{l}\text { Time } \\
(\min )\end{array}$ & $\begin{array}{l}\mathrm{q}_{\mathrm{m}, \mathrm{L}} \\
(\mathrm{mmol} \\
\left.\mathrm{Cr} \mathrm{g}^{-1}\right)\end{array}$ & $\begin{array}{l}\mathrm{b}_{\mathrm{L}}(\mathrm{L} \\
\mathrm{mmol}^{-} \\
\left.{ }^{1}\right)\end{array}$ & Ref. \\
\hline Clay & 3 & 50 & 1.22 & 5.46 & {$[72]$} \\
\hline Chitosan/Clay & 2 & 50 & 1.54 & 5.56 & {$[72]$} \\
\hline Clay/ $\mathrm{Fe}_{3} \mathrm{O}_{4}$ & 3 & 50 & 1.87 & 5.77 & \\
\hline $\begin{array}{l}\text { Chitosan/polyvinyl alcohol/ } \\
\text { activate carbon biocomposite }\end{array}$ & 2 & 180 & 2.11 & 18.7 & [73] \\
\hline Chitosan/Clay/ $\mathrm{Fe}_{3} \mathrm{O}_{4}$ & 2 & 50 & 2.26 & 4.78 & [72] \\
\hline $\begin{array}{l}\text { Humic acid coated nitrogen- } \\
\text { doped magnetic porous carbon } \\
\text { (HA-N-MPC) }\end{array}$ & 2 & 2880 & 2.51 & 919 & {$[11]$} \\
\hline $\begin{array}{l}\text { Core@shell structural Fe- } \\
\mathrm{Fe}_{2} \mathrm{O}_{3} @ \mathrm{PHCP}\end{array}$ & 2 & 60 & 5.44 & 11.2 & {$[74]$} \\
\hline Alginate/PEI foam & 2 & 4320 & 5.73 & 30.2 & {$[71]$} \\
\hline $\begin{array}{l}\text { Poly (4-vinyl pyridine) decorated } \\
\text { magnetic chitosan biopolymer }\end{array}$ & 2 & 180 & 6.63 & 2.44 & [75] \\
\hline $\begin{array}{l}\text { Biogenic mackinawite (FeS)- } \\
\text { depos- ited kaolinite }\end{array}$ & 7 & 60 & 7.67 & - & {$[76]$} \\
\hline Bermuda grass activated carbon & 2 & 600 & 7.75 & 5.20 & [19] \\
\hline $\begin{array}{l}\text { N-methylimidazolium- } \\
\text { functionalized KCC-1 (MI-Cl- } \\
\text { KCC-1) }\end{array}$ & 4 & 240 & 8.23 & 57.2 & [77] \\
\hline U-CALGB-MB 1.5 & 3 & 90 & 9.96 & 0.78 & $\begin{array}{l}\text { This } \\
\text { work }\end{array}$ \\
\hline
\end{tabular}

accurateness of mathematical fits). The figure gives a first evaluation of the quality of these fits and more specifically that the Langmuir and the Sips equations offer a quite good modeling of experimental profiles. The Langmuir equation supposes sorbent binding to occur through monolayer sorption, without interactions between sorbed molecules and with homogeneous energy of sorption at the surface of the sorbent. The Sips equation is a mathematical refinement of the Langmuir equation that combines the exponential term of the Freundlich equation. The inclusion of a third-adjustable parameter is supposed to improve the mathematical fitting of experimental data. The Freundlich empirical equation fails to describe the initial section of the curve; in addition, the power-type mathematical function does not allow simulating the saturation plateau. This empirical equation was correlated to the sorption behavior of heterogeneous sorbents. Apparently, despite the diversity of interaction modes involved in chromate removal, these energetic heterogeneities are not sufficient to force the fitting of experimental profiles with the Freundlich equation. On the other side, the Temkin equation supposes that the heat of adsorption linearly decreases with the increase in surface coverage. This equation is frequently used for describing systems where lateral interactions exist between sorbed molecules. The Temkin equation is also preferred for describing sorption profiles in the intermediary range of concentration. Herein, the Temkin fit notably overestimates the sorption capacity at low metal concentration and underevaluate the sorption capacities at the highest concentrations. The fail of the Temkin equation confirms the hypotheses of the Langmuir equation concerning the independency of sorbed metal species at the surface of the sorbent. The comparison of the Langmuir and the Sips equation shows very similar determination coefficients $\left(R^{2}: 0.997\right.$ and 0.998, respectively) and comparable AIC values (i.e., -67.5 and -68.9); the commonly-accepted condition for considering that the models show significantly different fitting accurateness is $\mid \mathrm{AICl}>2$ [68]. This is not the case here (i.e., $\mid \mathrm{AICl}=1.5$ ). Actually, the value of $\mathrm{n}_{\mathrm{S}}$ is close to the unity (i.e., 1.09) as a confirmation of the negligible contribution of the Freundlich term in the improvement of the quality of experimental fit. Despite the complexity and diversity of the mechanisms involved in chromate removal, the Langmuir equation appears to be the most appropriate for modeling sorption isotherm. For this reason, this model was used for fitting the sorption isotherms at different temperatures and for calculating the thermodynamic parameters (section 3.3.5.).

Table 4 compares the sorption performances (optimum $\mathrm{pH}$, kinetic indication through equilibrium time and sorption parameters such as
Table 5

Langmuir parameters for $\mathrm{Cr}(\mathrm{VI})$ sorption isotherms at different temperatures.

\begin{tabular}{llllll}
\hline $\begin{array}{l}\text { Temperature } \\
\left({ }^{\circ} \mathrm{C}\right)\end{array}$ & $\begin{array}{l}\mathrm{q}_{\mathrm{m}, \text { exp. }} \\
(\mathrm{mmol} \mathrm{Cr} \\
\left.\mathrm{g}^{-1}\right)\end{array}$ & $\begin{array}{l}\mathrm{q}_{\mathrm{m}, \mathrm{L}} \\
(\mathrm{mmol} \mathrm{Cr} \\
\left.\mathrm{g}^{-1}\right)\end{array}$ & $\begin{array}{l}\mathrm{b}_{\mathrm{L}}(\mathrm{L} \\
\mathrm{mmol}^{-} \\
1)\end{array}$ & $\mathrm{R}^{2}$ & $\mathrm{R}_{\mathrm{L}}$ \\
\hline 25 & 8.53 & 9.96 & 0.781 & 0.997 & $0.87-0.06$ \\
35 & 8.50 & 9.74 & 0.895 & 0.998 & $0.85-0.05$ \\
45 & 8.52 & 9.27 & 1.30 & 0.997 & $0.80-0.04$ \\
55 & 8.53 & 9.01 & 2.74 & 0.997 & $0.66-0.02$ \\
\hline
\end{tabular}

$\mathrm{R}_{\mathrm{L}}$ : favorability sorption factor, $R_{L}=\left(1+b_{L} \times C_{0}\right)^{-1}$.

capacity and affinity). This table shows the superior performances of $\mathrm{U}$ CALGB-MB 1.5 , especially in terms of equilibrium time and maximum sorption capacity. The unique weakness is associated with the low value of the affinity coefficient. It means that the sorbent requires relatively high metal concentrations to express its high sorption potential. Comparatively, metal sorption at low metal concentration is significantly reduced; however, even with a residual concentration of 0.5 mmol $\mathrm{Cr} \mathrm{g}^{-1}$ (i.e., $26 \mathrm{mg} \mathrm{L}^{-1}$ ) the sorption capacity remains relatively high compared to other sorbents (i.e., $2.8 \mathrm{mmol} \mathrm{Cr}^{-1}$ ).

\subsubsection{Effect of temperature on Cr(VI) sorption - Thermodynamics}

Fig. S14 compares the sorption isotherms for different temperatures ranging between 25 and $55{ }^{\circ} \mathrm{C}$. It is noteworthy that the sorption capacity at saturation is the same for the different temperatures (i.e., in the range 8.5-8.53 $\mathrm{mmol} \mathrm{Cr}^{-1}$ ). The most significant changes are detected in the initial sections of the curves: the affinity coefficient (which is proportional to the initial slope) increases with temperature, especially above $35^{\circ} \mathrm{C}$. Table 5 summarizes the parameters of the Langmuir model for the different isotherms: the sorption capacity at saturation of the monolayer (i.e., $\mathrm{q}_{\mathrm{m}, \mathrm{L}}$ ) slightly decreases with the increase of temperature while a reciprocal trend is observed for the affinity coefficient (i.e., $b_{\mathrm{L}}$ ). The affinity coefficient was corrected to make the affinity coefficient a dimensionless parameter $\left(b_{L} *=b_{L} \times 55.51,[69,70]\right)$ prior to application of the van't Hoff equation for the determination of the thermodynamic parameters:

$\ln b_{L}^{*}=\frac{-\Delta H^{0}}{R T}+\frac{\Delta S}{R}$

$\Delta G^{0}=\Delta H^{0}-T \Delta S^{0}$

where $\mathrm{R}$ is the universal gas constant $\left(8.314 \mathrm{~J} \mathrm{~mol}^{-1} \mathrm{~K}^{-1}\right)$ and $\mathrm{T}$ the absolute temperature (K); $\Delta \mathrm{H}^{\circ}, \Delta \mathrm{G}^{\circ}$ and $\Delta \mathrm{S}^{\circ}$ are the enthalpy change $(\mathrm{kJ}$ $\left.\mathrm{mol}^{-1}\right)$, the free Gibbs energy change $\left(\mathrm{kJ} \mathrm{mol}^{-1}\right)$ and the entropy change $\left(\mathrm{J} \mathrm{mol}^{-1} \mathrm{~K}^{-1}\right)$.

Fig. S15 shows the van't Hoff representation of thermodynamic data (Eq. 3a). The linearity of the plot is relatively weak. The data should then be considered as an indicator of the order of magnitude of thermodynamic parameters. From the slope of the curve, the enthalpy change can be evaluated to $33.27 \mathrm{~kJ} \mathrm{~mol}^{-1}$ while the entropy change can be calculated from the ordinate intercept to $141.7 \mathrm{~J} \mathrm{~mol}^{-1} \mathrm{~K}^{-1}$. The positive value of $\Delta \mathrm{H}^{\circ}$ means that the sorption process is endothermic. On the other hand, the positive value for entropy change means that the randomness of the system increases at the surface of the sorbent during sorption. The negative value of the free Gibbs energy change shows that the reaction is spontaneous and the increase of its absolute value with temperature $\left(\left|\Delta \mathrm{G}^{\circ}\right|\right.$ : from 9 to $\left.13 \mathrm{~kJ} \mathrm{~mol}^{-1}\right)$ means that the temperature favors the removal of chromate. This is confirmed by the variation of the favorability sorption factor (i.e., $\mathrm{R}_{\mathrm{L}}$, Table 5 ). The $\mathrm{R}_{\mathrm{L}}$ values are systematically lower than 1 : the sorption is favorable; $R_{L}$ decreases with the increase of both the concentration and the temperature.

\subsubsection{Effect of $\mathrm{NaCl}$}

The effect of the presence of salt was tested using $\mathrm{NaCl}$ as the background salt (Fig. S16) at $\mathrm{pH}_{0} 3$. The figure shows that the presence 
Table 6

Sorbent recycling.

\begin{tabular}{llll}
\hline \multirow{2}{*}{ Cycle \# } & Sorption & & $\begin{array}{l}\text { Desorption } \\
\text { efficiency (\%) }\end{array}$ \\
\cline { 2 - 3 } & $\mathrm{q}_{\mathrm{eq}}\left(\mathrm{mmol} \mathrm{Cr} \mathrm{g}^{-1}\right)$ & Loss (\%) & \\
\hline 1 & 1.199 & - & 98.7 \\
2 & 1.185 & 1.1 & 98.8 \\
3 & 1.175 & 2.0 & 98.2 \\
4 & 1.154 & 3.7 & 97.4 \\
5 & 1.147 & 4.3 & 96.1 \\
Cumul. @ 5 ${ }^{\text {th }}$ cycle & & & 97.8 \\
\hline
\end{tabular}

of chloride ions induces a significant decrease in $\mathrm{Cr}(\mathrm{VI})$ sorption capacity: at the $0.77 \mathrm{M} \mathrm{NaCl}$ dosage, the loss in sorption capacity reaches up to $26 \%$. The speciation of chromate is not affected by the introduction of $\mathrm{NaCl}$ at a concentration as high as $0.77 \mathrm{mM}$. Therefore, the effect cannot be related to the changes in chromate species. The stability of the dye may be also affected by the presence of $\mathrm{NaCl}$ since frequently dye desorption is processed using $\mathrm{NaCl}$ alkaline solutions in wastewater treatment. A release of the dye could influence the density of sorption sites but also the competition of dye in solution with immobilized dyes for the binding of chromate anions. However, the dosage of dye in the solution showed that the loss of dye at the highest $\mathrm{NaCl}$ level does not exceed $0.07 \%$ (Table S3). The effect of $\mathrm{NaCl}$ can result from a competition effect of chloride ions: at the highest $\mathrm{NaCl}$ level, the concentration of chloride ions is about double of the concentration of the different chromate species. Sodium and chloride ions may act as screening layers that reduce the reactivity of functional groups.

The $\log _{10}$ plot of the distribution ratio $v s$. the concentration of $\mathrm{NaCl}$ added to the solution is linear for concentrations higher than $0.25 \mathrm{mM}$ $\mathrm{NaCl}$. The slope is close to 1.08 . This could indicate that chromate is exchanged with chloride ion on the basis of a 1:1 stoichiometry. This effect can be used for promoting the desorption of chromate from UCALGB-MB 1.5 (see Section 3.3.7.).

\subsection{7. $\operatorname{Cr}(V I)$ desorption and sorbent recycling}

The desorption of chromate was carried out using alkaline $\mathrm{NaCl}$ solutions ( $2 \mathrm{M} \mathrm{NaCl} / 0.5 \mathrm{M} \mathrm{NaOH}$ ). The alkaline media favors the deprotonation of reactive groups weakening the interaction of the support with chromate anions. In addition, the high concentration of $\mathrm{NaCl}$ brings the competition of chloride anions. The conjunction of these two effects may explain the high desorption efficiency observed for five successive cycles of sorption and desorption (Table 6). The desorption efficiency slightly decreases but even at the fifth cycle the desorption maintains greater than $96 \%$; the cumulative desorption efficiency after 5 cycles is close to $97.8 \%$. On the other side, the comparison of the sorption performance at the different cycles shows that the sorption capacity remains remarkably stable: the loss in sorption capacity remains lower than 5\%. Fig. S17 compares the FTIR spectrum of the sorbent after 5 reuses with the reference spectrum (sorbent as-produced): the sorbent is remarkably stable without detectable differences. I addition, the limited loss of dye along with the cycles (at the fifth cycle the cumulative loss of dye is below $0.6 \%$, Table S3). Despite the different mechanisms involved in chromate removal the desorption and recycling efficiencies are maintained relatively constant. This must be highlighted since the reduction phenomena of chromate are frequently suspected to decrease the efficiency in metal recovery at long-use and recycling [71].

\subsubsection{Application to spiked effluents}

The compositions of the two industrial effluents that were spiked with increasing concentrations are reported in Table S2. Fig. 6 shows the comparison of sorption capacities for the two effluents and 4 different spiked concentrations of chromate while using U-CALGB-MB ${ }_{1.5}$ at $\mathrm{pH}_{0} 3$. The profiles are compared with the data obtained on synthetic pure solutions. Despite the relative complexity of the wastewater from the petrochemical unit (compared with tap water), the sorption properties are remarkably similar, and only a little lower than the performance obtained with synthetic solutions. The loss in sorption capacity slightly increases with the concentration of chromate in the spiked solutions. Compared with synthetic solutions, the sorption capacity decreased by $8.4 \%$ for tap water and up to $11.2 \%$ for petrochemical unit wastewater (at $\mathrm{C}_{0}: 0.385 \mathrm{mmol} \mathrm{Cr} \mathrm{L}^{-1}$ ). The utilization of sorption sites (UOS) remains higher than $88 \%$. These complementary results on real-like effluents confirm the potential of these materials for $\mathrm{Cr}(\mathrm{VI})$ recovery from aqueous solutions with high sorption capacities and fast uptake kinetics.

\section{Conclusion}

The incorporation of urea in calcium alginate beads (produced for the upcycling of waste materials such as alga biomass and bi-valve shells) allows synthesizing a sorbent (U-CALGB) with a high affinity for methylene blue. Sorption capacity reaches $1.5 \mathrm{mmol} \mathrm{MB} \mathrm{g}^{-1}$ at $\mathrm{pH}$ 5.8. This level of loading allows reaching a maximum for $\mathrm{Cr}(\mathrm{VI})$ uptake. The un-controlled drying of the beads leads to a relatively weak specific surface area (16-12 $\mathrm{m}^{2} \mathrm{~g}^{-1}$ with limited porous volume and thin pore size). Using alternative drying processes such as freeze-drying or drying under supercritical $\mathrm{CO}_{2}$ conditions would probably contribute to

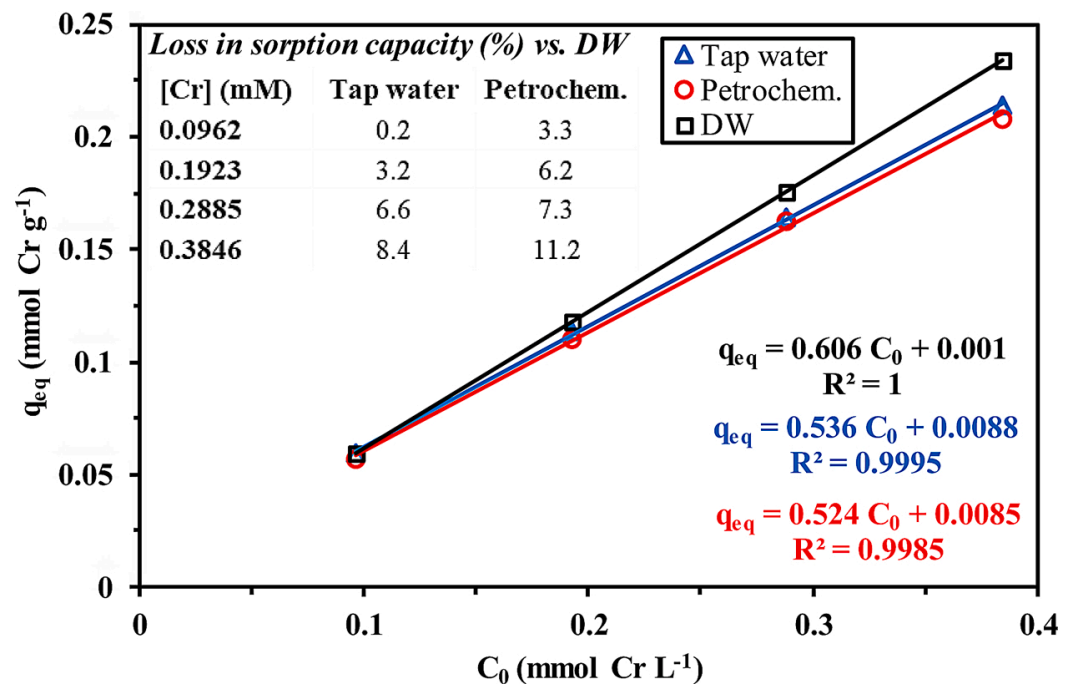

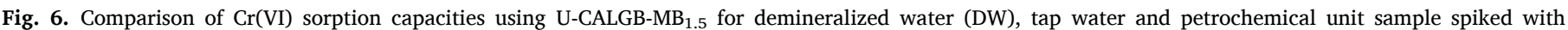
increasing metal concentrations ( $\mathrm{pH}_{0} 3 ; \mathrm{C}_{0}$ : 0.096-0.385 mmol Cr L ${ }^{-1}$; SD: $1.5 \mathrm{~g} \mathrm{~L}^{-1}$; Agitation: $200 \mathrm{rpm}$; Time: $90 \mathrm{~min}$; $\left.\mathrm{T}: 25 \pm 1{ }^{\circ} \mathrm{C}\right)$. 
enhancing porous properties. The $\mathrm{pH}_{\mathrm{PZC}}$ value of the sorbent (close to 6.07) means that it is positively charged in acidic solutions and then able to bind chromate anions at $\mathrm{pH} 3$, which is the optimum $\mathrm{pH}$. In acidic media (i.e. pH 3 and below), a significant reduction of chromate to $\mathrm{Cr}$ (III) makes complex the interpretation of chromium binding. The presence of different functional groups (coming from the algal biomass, urea and the dye) combines different modes of interactions: ion- exchange/ electrostatic attraction, complexation, and reduction. Maximum sorption capacity for $\mathrm{Cr}(\mathrm{VI})$ reaches up to $8.53 \mathrm{mmol} \mathrm{Cr} \mathrm{g}^{-1}$; making this sorbent one of the most efficient reported in the literature. The sorption isotherm at $\mathrm{pH} 3$ is well described by the Langmuir equation. Despite the limited porosity of the sorbent, uptake kinetics are relatively fast: a contact time of $30-60 \mathrm{~min}$ is sufficient for reaching the equilibrium. The kinetic profiles are finely fitted by the pseudo-second order rate equation. The presence of $\mathrm{NaCl}$ slightly reduces chromate sorption dues to charge screening and competition of chloride ions. However, the sorption capacity remains close to $0.9 \mathrm{mmol} \mathrm{Cr} \mathrm{g}^{-1}$ in the presence of 0.77 $\mathrm{mmol} \mathrm{Cl} \mathrm{L}{ }^{-1}$. It is noteworthy that the dye remains tightly-bound to the support despite drastic $\mathrm{pH}$ and background salt conditions. This may explain that even in the presence of $2 \mathrm{M} \mathrm{NaCl} / 0.5 \mathrm{M} \mathrm{NaOH}$ (the eluent used for chromate desorption), dye release is negligible and the sorption and desorption properties are stable for a minimum of five cycles. The robustness of the process is confirmed by the relative stability in sorption properties for $\mathrm{Cr}(\mathrm{VI})$-spiked solutions of increasing complexity (i.e., tap water and petrochemical wastewater sample).

\section{Consent to participate}

All authors agree and approved this manuscript.

\section{CRediT authorship contribution statement}

Khalid Z. Elwakeel: Conceptualization, Methodology, Data curation, Investigation. Ahmed M. Elgarahy: Methodology, Investigation, Writing - original draft. Eric Guibal: Conceptualization, Investigation, Writing - review \& editing.

\section{Declaration of Competing Interest}

The authors declare that the manuscript was not published (and is not considered elsewhere for publication), that this is an original contribution and that the support reported at the end of the manuscript is not creating any conflict of interest.

\section{Acknowledgements}

The authors acknowledge the support of Institut Français d'Egypte for structuring the collaboration network between IMT - Mines Ales and Egyptian institutions (including Port-Said University).

\section{Appendix A. Supplementary data}

Supplementary material related to this article can be found, in the online version, at doi:https://doi.org/10.1016/j.jece.2020.104767.

\section{References}

[1] F. Almomani, R. Bhosale, M. Khraisheh, A. kumar, T. Almomani, Heavy metal ions removal from industrial wastewater using magnetic nanoparticles (MNP), Appl. Surf. Sci. 506 (2020), 144924.

[2] A.R. Mahmood, M.A. Alheety, M.M. Asker, A.Z. Tareq, A. Karadağ, Saccharine based carbonyl multi-walled carbon nanotubes: novel modification, characterization and its ability for removing Cd (II) and Cu (II) from soil and environmental water samples, Journal of Physics: Conference Series, IOP Publishing (2019) 052003.

[3] M.A. Alheety, A. Raoof, S.A. Al-Jibori, A. Karadağ, A.I. Khaleel, H. Akbaș, O. Uzun, Eco-friendly C60-SESMP-Fe3O4 inorganic magnetizable nanocomposite as high- performance adsorbent for magnetic removal of arsenic from crude oil and water samples, Mater. Chem. Phys. 231 (2019) 292-300.

[4] L. Nirumand, S. Farhadi, A. Zabardasti, A. Khataee, Synthesis and sonocatalytic performance of a ternary magnetic MIL-101(Cr)/RGO/ZnFe2O4 nanocomposite for degradation of dye pollutants, Ultrason. Sonochem. 42 (2018) 647-658.

[5] L.R. Bonetto, J.S. Crespo, R. Guégan, V.I. Esteves, M. Giovanela, Removal of methylene blue from aqueous solutions using a solid residue of the apple juice industry: full factorial design, equilibrium, thermodynamics and kinetics aspects, J. Mol. Struct. 1224 (2021), 129296.

[6] G. Alvarenga, J.P. Lima, A.C.F. Goszczynski, C.H. Rosa, G.R. Rosa, T.J. Lopes, Methylene blue adsorption by timbaúva (Enterolobium contortisiliquum)-derived materials, Environ. Sci. Pollut. Res. - Int. 27 (2020) 27893-27903.

[7] A. Miclescu, L. Wiklund, Methylene blue, an old drug with new indications? Jurnalul Roman de Anestezie Terapie Intaensiva 17 (2010) 35-41.

[8] J. Lee, J.-A. Park, H.-G. Kim, J.-H. Lee, S.-H. Cho, K. Choi, K.-W. Jung, S.Y. Lee, J. W. Choi, Most suitable amino silane molecules for surface functionalization of graphene oxide toward hexavalent chromium adsorption, Chemosphere 251 (2020), 126387.

[9] K. Nithya, A. Sathish, P.S. Kumar, Packed bed column optimization and modeling studies for removal of chromium ions using chemically modified Lantana camara adsorbent, J. Water Process Eng. 33 (2020), 101069.

[10] F. Ogata, N. Nagai, R. Itami, T. Nakamura, N. Kawasaki, Potential of virgin and calcined wheat bran biomass for the removal of chromium(VI) ion from a synthetic aqueous solution, J. Environ. Chem. Eng. 8 (2020), 103710.

[11] T. Zhang, S. Wei, G.I.N. Waterhouse, L. Fu, L. Liu, W. Shi, J. Sun, S. Ai, Chromium (VI) adsorption and reduction by humic acid coated nitrogen-doped magnetic porous carbon, Powder Technol. 360 (2020) 55-64.

[12] K. Yan, Z. Liu, Z. Li, R. Yue, F. Guo, Z. Xu, Selective separation of chromium from sulphuric acid leaching solutions of mixed electroplating sludge using phosphate precipitation, Hydrometallurgy 186 (2019) 42-49.

[13] A. Martín-Domínguez, M.L. Rivera-Huerta, S. Pérez-Castrejón, S.E. Garrido-Hoyos, I.E. Villegas-Mendoza, S.L. Gelover-Santiago, P. Drogui, G. Buelna, Chromium removal from drinking water by redox-assisted coagulation: chemical versus electrocoagulation, Sep. Purif. Technol. 200 (2018) 266-272.

[14] Y. Wang, J. Li, Y. Jin, M. Chen, R. Ma, Extraction of chromium (III) from aqueous waste solution in a novel rotor-stator spinning disc reactor, Chem. Eng. Process. Process Intensif. 149 (2020), 107834.

[15] H. Wang, X. Song, H. Zhang, P. Tan, F. Kong, Removal of hexavalent chromium in dual-chamber microbial fuel cells separated by different ion exchange membranes, J. Hazard. Mater. 384 (2020), 121459.

[16] H. Lin, Y. Li, J. Zhu, Cross-linked GO membranes assembled with GO nanosheets of differently sized lateral dimensions for organic dye and chromium separation, J. Membr. Sci. 598 (2020), 117789.

[17] T. Shahnaz, M.M.F. S, P. V.C, S. Narayanasamy, Surface modification of nanocellulose using polypyrrole for the adsorptive removal of Congo red dye and chromium in binary mixture, Int. J. Biol. Macromol. 151 (2020) 322-332.

[18] D. Huang, G. Wang, Z. Li, F. Kang, F. Liu, Investigation of the removal mechanism of $\mathrm{Cr}(\mathrm{VI})$ in groundwater using activated carbon and cast iron combined system, Environ. Sci. Pollut. Res. 24 (2017) 18341-18354.

[19] B. Tu, R. Wen, K. Wang, Y. Cheng, Y. Deng, W. Cao, K. Zhang, H. Tao, Efficient removal of aqueous hexavalent chromium by activated carbon derived from Bermuda grass, J. Colloid Interface Sci. 560 (2020) 649-658.

[20] A.K. Mohamed, M.E. Mahmoud, Nanoscale Pisum sativum pods biochar encapsulated starch hydrogel: a novel nanosorbent for efficient chromium (VI) ions and naproxen drug removal, Bioresour. Technol. 308 (2020), 123263.

[21] E. Rodrigues, O. Almeida, H. Brasil, D. Moraes, M.A.L. dos Reis, Adsorption of chromium (VI) on hydrotalcite-hydroxyapatite material doped with carbon nanotubes: equilibrium, kinetic and thermodynamic study, Appl. Clay Sci. 172 (2019) 57-64.

[22] T. Shahnaz, C. Patra, V. Sharma, N. Selvaraju, A comparative study of raw, acid modified and EDTA-complexed Acacia auriculiformis biomass for the removal of hexavalent chromium, Chem. Ecol. 36 (2020) 360-381.

[23] J. Ali, L. Wang, H. Waseem, R. Djellabi, N.A. Oladoja, G. Pan, FeS@rGO nanocomposites as electrocatalysts for enhanced chromium removal and clean energy generation by microbial fuel cell, Chem. Eng. J. 384 (2020), 123335.

[24] K. Henryk, C. Jaroslaw, Z. Witold, Peat and coconut fiber as biofilters for chromium adsorption from contaminated wastewaters, Environ. Sci. Pollut. Res. 23 (2016) 527-534.

[25] C. Kang, P. Wu, L. Li, L. Yu, B. Ruan, B. Gong, N. Zhu, Cr(VI) reduction and Cr(III) immobilization by resting cells of Pseudomonas aeruginosa CCTCC AB93066: spectroscopic, microscopic, and mass balance analysis, Environ. Sci. Pollut. Res. 24 (2017) 5949-5963.

[26] T. Shahnaz, V. Sharma, S. Subbiah, S. Narayanasamy, Multivariate optimisation of $\mathrm{Cr}$ (VI), Co (III) and Cu (II) adsorption onto nanobentonite incorporated nanocellulose/chitosan aerogel using response surface methodology, J. Water Process. Eng. 36 (2020), 101283.

[27] S. Kumar, T. Shahnaz, N. Selvaraju, P.V. Rajaraman, Kinetic and thermodynamic studies on biosorption of $\mathrm{Cr}(\mathrm{VI})$ on raw and chemically modified Datura stramonium fruit, Environ. Monit. Assess. 192 (2020) 248.

[28] K. Nithya, A. Sathish, K. Pradeep, S.K. Baalaji, Algal biomass waste residues of Spirulina platensis for chromium adsorption and modeling studies, J. Environ. Chem. Eng. 7 (2019), 103273.

[29] C. Lei, C. Wang, W. Chen, M. He, B. Huang, Polyaniline@magnetic chitosan nanomaterials for highly efficient simultaneous adsorption and in-situ chemical reduction of hexavalent chromium: removal efficacy and mechanisms, Sci. Total Environ. 733 (2020), 139316. 
[30] H.L. Vasconcelos, E. Guibal, R. Laus, L. Vitali, V.T. Favere, Competitive adsorption of $\mathrm{Cu}(\mathrm{II})$ and $\mathrm{Cd}(\mathrm{II})$ ions on spray-dried chitosan loaded with Reactive Orange 16 Mater. Sci. Eng., C 29 (2009) 613-618.

[31] A.M. Elgarahy, K.Z. Elwakeel, S.H. Mohammad, G.A. Elshoubaky, Multifunctiona eco-friendly sorbent based on marine brown algae and bivalve shells for subsequent uptake of Congo red dye and copper(II) ions, J. Environ. Chem. Eng. 8 (2020), 103915.

[32] M. Rawat, A.P. Rawat, K. Giri, J.P.N. Rai, Cr(VI) sorption by free and immobilised chromate-reducing bacterial cells in PVA-alginate matrix: equilibrium isotherms and kinetic studies, Environ. Sci. Pollut. Res. 20 (2013) 5198-5211.

[33] S.T. Aldmour, I.T. Burke, A.W. Bray, D.L. Baker, A.B. Ross, F.L. Gill, G. Cibin, M. E. Ries, D.I. Stewart, Abiotic reduction of $\mathrm{Cr}(\mathrm{VI})$ by humic acids derived from peat and lignite: kinetics and removal mechanism, Environ. Sci. Pollut. Res. 26 (2019) $4717-4729$.

[34] A. Lace, D. Ryan, M. Bowkett, J. Cleary, Chromium monitoring in water by colorimetry using optimised 1,5-diphenylcarbazide method, Int. J. Environ. Res. Public Health 16 (2019), 1803.

[35] N. Guo, X. Lv, Q. Li, T. Ren, H. Song, Q. Yang, Removal of hexavalent chromium from aqueous solution by mesoporous $\alpha-\mathrm{FeOOH}$ nanoparticles: performance and mechanism, Microporous Mesoporous Mater. 299 (2020), 110101.

[36] R. Valentin, R. Horga, B. Bonelli, E. Garrone, F. Di Renzo, F. Quignard, Acidity of alginate aerogels studied by FTIR spectroscopy of probe molecules, Makromol. Chem. Macromol. Symp. 230 (2005) 71-77.

[37] R.R. Escudero, M. Robitzer, F. Di Renzo, F. Quignard, Alginate aerogels as adsorbents of polar molecules from liquid hydrocarbons: hexanol as probe molecule, Carbohydr. Polym. 75 (2009) 52-57.

[38] P. Dos Santos Araujo, G.B. Belini, G.P. Mambrini, F.M. Yamaji, W.R. Waldman, Thermal degradation of calcium and sodium alginate: a greener synthesis towards calcium oxide micro/nanoparticles, Int. J. Biol. Macromol. 140 (2019) 749-760.

[39] A. Nejadebrahim, M. Ebrahimi, X. Allonas, C. Croutxé-Barghorn, Methylene blueclay nano-pigment as a new photosensitizer for preparing three-component photoinitiating systems with high thermal stability, Dye. Pigment. 180 (2020), 108475.

[40] D. Leal, B. Matsuhiro, M. Rossi, F. Caruso, FT-IR spectra of alginic acid block fractions in three species of brown seaweeds, Carbohydr. Res. 343 (2008) 308-316.

[41] A.A. Hameed, M.A. Alheety, A.R. Mahmood, S.A. Al-Jibori, A. Karadag, H2 storage abilities of some novel Pd(II) complexes containing 2H[1,4]benzothiazin-3(4H)one, Inorg. Chem. Commun. 106 (2019) 11-17.

[42] A.S.M. Al-Janabi, O.a.A.Y. Al-Samrai, M.A. Alheety, Novel Mercury(II) 1-Phenyl1H-tetrazol-5-thiol and carbon nanotube complexes: synthesis, characterization and H2 storage capacities, Chem. Data Collect. 28 (2020), 100399.

[43] J. Grdadolnik, Y. Maréchal, Urea and urea-water solutions-an infrared study, J. Mol. Struct. 615 (2002) 177-189.

[44] A. Benettayeb, E. Guibal, A. Morsli, R. Kessas, Chemical modification of alginate for enhanced sorption of Cd(II), Cu(II) and Pb(II), Chem. Eng. J. 316 (2017) 704-714.

[45] O.V. Ovchinnikov, A.V. Evtukhova, T.S. Kondratenko, M.S. Smirnov, V. Y. Khokhlov, O.V. Erina, Manifestation of intermolecular interactions in FTIR spectra of methylene blue molecules, Vib. Spectrosc. 86 (2016) 181-189.

[46] J. Coates, Interpretation of infrared spectra, a practical approach. Encyclopedia of Analytical Chemistry, John Wiley \& Sons, Ltd., 2006, pp. 1-23.

[47] M. Alcolea Palafox, M. Gil, J.L. Núñez, G. Tardajos, Study of phenothiazine and Nmethyl phenothiazine by infrared, raman, 1H-, and 13C-NMR spectroscopies, Int. J. Quantum Chem. 89 (2002) 147-171.

[48] G. Zaitseva, Y. Gushikem, E.S. Ribeiro, S.S. Rosatto, Electrochemical property of methylene blue redox dye immobilized on porous silica-zirconia-antimonia mixed oxide, Electrochim. Acta 47 (2002) 1469-1474.

[49] E. Poteet, A. Winters, L.-J. Yan, K. Shufelt, K.N. Green, J.W. Simpkins, Y. Wen, S.H. Yang, Neuroprotective actions of Methylene Blue and its derivatives, PLoS One 7 (2012), e48279.

[50] O. Blank, E. Davioud-Charvet, M. Elhabiri, Interactions of the antimalarial drug methylene blue with methemoglobin and heme targets in Plasmodium falciparum: a physico-biochemical study, Antioxid. Redox Signaling 17 (2012) 544-554.

[51] J.J. Salazar-Rabago, R. Leyva-Ramos, J. Rivera-Utrilla, R. Ocampo-Perez, F. J. Cerino-Cordova, Biosorption mechanism of Methylene Blue from aqueous solution onto white pine (Pinus durangensis) sawdust: effect of operating conditions, Sustain. Environ. Res. 27 (2017) 32-40.

[52] A.S. Assémian, K.E. Kouassi, K. Adouby, P. Drogui, D. Boa, Removal of Methylene Blue in aqueous solutions by electrocoagulation process: adsorption, kinetics, studies, Eur. J. Chem. 9 (2018) 311-316.

[53] A. Haug, Dissociation of alginic acid, Acta Chem. Scand. 15 (1961) 950-952.

[54] A. Fernandez-Perez, T. Valdes-Solis, G. Marban, Visible light spectroscopic analysis of Methylene Blue in water; the resonance virtual equilibrium hypothesis, Dyes Pigm. 161 (2019) 448-456.
[55] E.S. Dragan, D.F.A. Loghin, Enhanced sorption of methylene blue from aqueous solutions by semi-IPN composite cryogels with anionically modified potato starch entrapped in PAAm matrix, Chem. Eng. J. 234 (2013) 211-222.

[56] M.M. Perju, M.V. Dinu, E.S. Dragan, Sorption of methylene blue onto ionic composite hydrogels based on polyacrylamide and dextran sulfate: kinetics, isotherms, and thermodynamics, Sep. Sci. Technol. 47 (2012) 1322-1333.

[57] V.J.P. Vilar, C.M.S. Botelho, R.A.R. Boaventura, Methylene blue adsorption by algal biomass based materials: biosorbents characterization and process behaviour, J. Hazard. Mater. 147 (2007) 120-132.

[58] E. Alver, A.Ü. Metin, F. Brouers, Methylene blue adsorption on magnetic alginate/ rice husk bio-composite, Int. J. Biol. Macromol. 154 (2020) 104-113.

[59] E.S. Ilton, C.O. Moses, D.R. Veblen, Using X-ray photoelectron spectroscopy to discriminate among different sorption sites of Micas: with implications for heterogeneous reduction of chromate at the mica-water interface, Geochim. Cosmochim. Acta 64 (2000) 1437-1450.

[60] R.W. Taylor, S.Y. Shen, W.F. Bleam, S.I. Tu, Chromate removal by dithionitereduced clays: evidence from direct X-ray adsorption near edge spectroscopy (XANES) of chromate reduction at clay surfaces, Clays Clay Miner. 48 (2000) 648-654.

[61] D. Park, S.-R. Lim, Y.-S. Yun, J.M. Park, Reliable evidences that the removal mechanism of hexavalent chromium by natural biomaterials is adsorption-coupled reduction, Chemosphere 70 (2007) 298-305.

[62] G.P. Gallios, M. Vaclavikova, Removal of chromium (VI) from water streams: a thermodynamic study, Environ. Chem. Lett. 6 (2008) 235-240.

[63] I. Bibi, N.K. Niazi, G. Choppala, E.D. Burton, Chromium(VI) removal by siderite (FeCO3) in anoxic aqueous solutions: an X-ray absorption spectroscopy investigation, Sci. Total Environ. 640 (2018) 1424-1431.

[64] C. Fan, C. Guo, Y. Zeng, Z. Tu, Y. Ji, J.R. Reinfelder, M. Chen, W. Huang, G. Lu, X. Yi, Z. Dang, The behavior of chromium and arsenic associated with redox transformation of schwertmannite in AMD environment, Chemosphere 222 (2019) 945-953.

[65] Z. Wang, W. Hu, Z. Kang, X. He, Z. Cai, B. Deng, Arsenate adsorption on ironimpregnated ordered mesoporous carbon: fast kinetics and mass transfer evaluation, Chem. Eng. J. 357 (2019) 463-472.

[66] M.A. Hubbe, S. Azizian, S. Douven, Implications of apparent pseudo-second-order adsorption kinetics onto cellulosic materials: a review, BioResources 14 (2019) 45.

[67] Y. Marcus, Ion Properties, Marcel Dekker, Inc., New York, NY, 1997.

[68] O. Falyouna, O. Eljamal, I. Maamoun, A. Tahara, Y. Sugihara, Magnetic zeolite synthesis for efficient removal of cesium in a lab-scale continuous treatment system, J. Colloid Interface Sci. 571 (2020) 66-79.

[69] P.S. Ghosal, A.K. Gupta, Determination of thermodynamic parameters from Langmuir isotherm constant-revisited, J. Mol. Liq. 225 (2017) 137-146.

[70] E.C. Lima, A. Hosseini-Bandegharaei, J.C. Moreno-Piraján, I. Anastopoulos, A critical review of the estimation of the thermodynamic parameters on adsorption equilibria. Wrong use of equilibrium constant in the Van't Hoof equation for calculation of thermodynamic parameters of adsorption, J. Mol. Liq. 273 (2019) 425-434.

[71] Y. Mo, S. Wang, T. Vincent, J. Desbrieres, C. Faur, E. Guibal, New highlypercolating alginate-PEI membranes for efficient recovery of chromium from aqueous solutions, Carbohydr. Polym. 225 (2019), 115177.

[72] R. Foroutan, S.J. Peighambardoust, R. Mohammadi, M. Omidvar, G.A. Sorial, B. Ramavandi, Influence of chitosan and magnetic iron nanoparticles on chromium adsorption behavior of natural clay: adaptive neuro-fuzzy inference modeling, Int. J. Biol. Macromol. 151 (2020) 355-365.

[73] R. Nowruzi, M. Heydari, V. Javanbakht, Synthesis of a chitosan/polyvinyl alcohol/ activate carbon biocomposite for removal of hexavalent chromium from aqueous solution, Int. J. Biol. Macromol. 147 (2020) 209-216.

[74] Z. Wang, Y. Wang, S. Cao, S. Liu, Z. Chen, J. Chen, Y. Chen, J. Fu, Fabrication of core@shell structural Fe- $\mathrm{Fe}_{2} \mathrm{O}_{3} @ \mathrm{PHCP}$ nanochains with high saturation magnetization and abundant amino groups for hexavalent chromium adsorption and reduction, J. Hazard. Mater. 384 (2020), 121483.

[75] C. Zheng, H. Zheng, Y. Sun, B. Xu, Y. Wang, X. Zheng, Y. Wang, Simultaneous adsorption and reduction of hexavalent chromium on the poly (4-vinyl pyridine) decorated magnetic chitosan biopolymer in aqueous solution, Bioresour. Technol. 293 (2019), 122038.

[76] Q. Li, Y. Zhang, Y. Liao, J. Huang, Z. Dang, C. Guo, Removal of hexavalent chromium using biogenic mackinawite (FeS)-deposited kaolinite, J. Colloid Interface Sci. 572 (2020) 236-245.

[77] R. Soltani, A. Marjani, M. Hosseini, S. Shirazian, Synthesis and characterization of novel N-methylimidazolium-functionalized KCC-1: a highly efficient anion exchanger of hexavalent chromium, Chemosphere 239 (2020), 124735. 